\title{
Emerging Fusarium and Alternaria Mycotoxins: Occurrence, Toxicity and Toxicokinetics
}

\author{
Sophie Fraeyman ${ }^{1}$ (D), Siska Croubels ${ }^{1, *}$, Mathias Devreese ${ }^{1}$ and Gunther Antonissen ${ }^{1,2}$ \\ 1 Department of Pharmacology, Toxicology and Biochemistry, Faculty of Veterinary Medicine, \\ Ghent University, Salisburylaan 133, 9820 Merelbeke, Belgium; sophie.fraeyman@ugent.be (S.F.); \\ mathias.devreese@ugent.be (M.D.); gunther.antonissen@ugent.be (G.A.) \\ 2 Department of Pathology, Bacteriology and Avian Diseases, Faculty of Veterinary Medicine, \\ Ghent University, Salisburylaan 133, 9820 Merelbeke, Belgium \\ * Correspondence: siska.croubels@ugent.be; Tel.: +32-9-264-7347
}

Academic Editor: Marc Maresca

Received: 31 May 2017; Accepted: 15 July 2017; Published: 18 July 2017

\begin{abstract}
Emerging Fusarium and Alternaria mycotoxins gain more and more interest due to their frequent contamination of food and feed, although in vivo toxicity and toxicokinetic data are limited. Whereas the Fusarium mycotoxins beauvericin, moniliformin and enniatins particularly contaminate grain and grain-based products, Alternaria mycotoxins are also detected in fruits, vegetables and wines. Although contamination levels are usually low ( $\mu \mathrm{g} / \mathrm{kg}$ range), higher contamination levels of enniatins and tenuazonic acid may occasionally occur. In vitro studies suggest genotoxic effects of enniatins A, A1 and B1, beauvericin, moniliformin, alternariol, alternariol monomethyl ether, altertoxins and stemphyltoxin-III. Furthermore, in vitro studies suggest immunomodulating effects of most emerging toxins and a reproductive health hazard of alternariol, beauvericin and enniatin B. More in vivo toxicity data on the individual and combined effects of these contaminants on reproductive and immune system in both humans and animals is needed to update the risk evaluation by the European Food Safety Authority. Taking into account new occurrence data for tenuazonic acid, the complete oral bioavailability, the low total body clearance in pigs and broiler chickens and the limited toxicity data, a health risk cannot be completely excluded. Besides, some less known Alternaria toxins, especially the genotoxic altertoxins and stemphyltoxin III, should be incorporated in risk evaluation as well.
\end{abstract}

Keywords: emerging mycotoxin; occurrence; toxicity; toxicokinetics; Fusarium; Alternaria

\section{Introduction}

Mycotoxins are low-molecular-weight secondary fungal metabolites that can contaminate various food and feed commodities, including but not limited to grain and grain-based products, vegetables, fruits and fruit juices, oil seeds and oils, spices, coffee and wine [1,2]. The continuous development of liquid chromatography coupled to mass spectrometric methods makes it possible to analyze an almost non-exhaustive list of mycotoxins in a variety of food and feed matrices [3,4]. These multi-mycotoxin screenings revealed a high prevalence of so called "emerging" mycotoxins. In feed for example, the Fusarium mycotoxins beauvericin (BEA), enniatins (ENNs) and moniliformin (MON) were detected in $98 \%, 96 \%$ and $76 \%$ of the feed and feed ingredient samples $(n=83)$, respectively. Eighty-two percent, $80 \%$ and $65 \%$ of the samples analyzed between 2010 and 2012 were contaminated with the Alternaria mycotoxins alternariol monomethyl ether (AME), alternariol (AOH) and tenuazonic acid (TeA), respectively [4]. Although these mycotoxins are frequently detected, no legislation or guideline is available and the in vivo toxicity data is limited. In vitro studies suggest genotoxic effects of BEA, ENN A, A1, B1, MON, AOH, AME, altertoxin-II (ATX-II) and stemphyltoxin-III (STTX-III) [5-10]. Besides, 
MON and TeA cause severe toxicity in animals, with MON mainly affecting the heart and TeA causing hemorrhages [11-14]. Therefore, these frequently detected food and feed contaminants could pose a health risk for humans and animals. In 2014 and 2011, the European Food Safety Authority (EFSA) disclosed some knowledge gaps regarding the occurrence, toxicity and toxicokinetics of BEA, ENNs and Alternaria toxins. Since then, new studies focusing on occurrence, toxicokinetics and metabolism of these emerging mycotoxins have been published [15-23]. Therefore, the objective of this review is to give an updated overview of the occurrence in food and feed, in vitro and in vivo toxicity and toxicokinetics of BEA, ENNs, MON and the Alternaria mycotoxins. In addition, remaining knowledge and research gaps in this field were identified. For an overview of other emerging mycotoxins, the authors would like to refer to the work of Gruber-Dorninger et al. (2016) [24].

\section{Beauvericin and Enniatins}

In the search for new antibiotics, BEA was isolated for the first time from Beauveria bassiana as early as in 1969 [25]. BEA and ENNs are cyclic depsipeptides produced by a wide variety of Fusarium fungi, including but not limited to F. acuminatum, F. avenaceum, F. oxysporum, F. poae, F. sporotrichioides, F. sambucinum and F. tricinctum [26-30]. Most frequently detected mycotoxins are BEA, ENN A, A1, B and B1 (Figure 1).

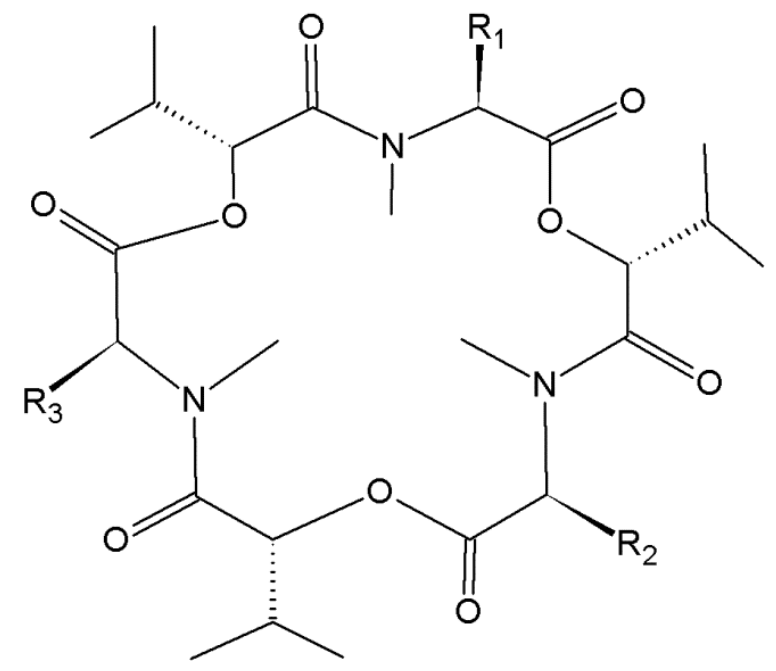

Figure 1. Chemical structure of beauvericin, enniatin $A, A 1, B$ and $B 1$. Beauvericin (BEA), R1 = R2 $=\mathrm{R} 3=$ phenylmethyl; Enniatin $\mathrm{A}(\mathrm{ENN} \mathrm{A}), \mathrm{R} 1=\mathrm{R} 2=\mathrm{R} 3=-\mathrm{CH}\left(\mathrm{CH}_{3}\right) \mathrm{CH}_{2} \mathrm{CH}_{3}$; Enniatin A1 $(\mathrm{ENN}$ $\mathrm{A} 1), \mathrm{R} 1=\mathrm{R} 2=-\mathrm{CH}\left(\mathrm{CH}_{3}\right) \mathrm{CH}_{2} \mathrm{CH}_{3}, \mathrm{R} 3=-\mathrm{CH}\left(\mathrm{CH}_{3}\right)_{2} ;$ Enniatin $\mathrm{B}(\mathrm{ENN} \mathrm{B}), \mathrm{R} 1=\mathrm{R} 2=\mathrm{R} 3=-\mathrm{CH}\left(\mathrm{CH}_{3}\right)_{2}$; Enniatin B1 (ENN B1), R1 = R2 =- $\mathrm{CH}\left(\mathrm{CH}_{3}\right)_{2}, \mathrm{R} 3=-\mathrm{CH}\left(\mathrm{CH}_{3}\right) \mathrm{CH}_{2} \mathrm{CH}_{3}$.

\subsection{Occurrence of Beauvericin and Enniatins in Food and Feed}

BEA and ENNs can contaminate a variety of foodstuffs (Table 1). Grain-based food products are the most important contributors to the acute and chronic dietary exposure [16]. BEA contaminated the majority of Scandinavian cereals, including wheat, oats, barley and rye. Prevalence ranged between $12 \%$ and $100 \%$. Mostly, contamination levels were below $100 \mu \mathrm{g} / \mathrm{kg}$. The highest concentration detected was $220 \mu \mathrm{g} / \mathrm{kg}$ in barley [17,31,32]. Compared to Scandinavian cereals, Moroccan samples contained much higher BEA levels, with a maximum contamination level of $26,300 \mu \mathrm{g} / \mathrm{kg}$ in rice. Moroccan breakfast cereals and couscous seemed not frequently contaminated (0-2.9\%), but Moroccan rice was highly contaminated (76\%). However, it should be noted that the limit of quantification (LOQ) in the studies of Mahnine et al. (2011) and Sifou et al. (2011) was rather high (500 $\mu \mathrm{g} / \mathrm{kg}$ ), which at least partly could explain the lower incidence of BEA in Moroccan cereals. The differences in LOQ 
could be attributed to the fact that both Mahnine et al. (2011) and Sifou et al. (2011) used LC-diode array detection (DAD) to determine BEA, whereas other authors used LC-MS [17,31-37].

Regarding ENNs, almost all Scandinavian cereal samples were contaminated, with a high prevalence (range $96 \%$ and 100\%). Contamination levels were usually in the $\mu \mathrm{g} / \mathrm{kg}$ range (median concentrations $41-569 \mu \mathrm{g} / \mathrm{kg}$ ), but could occasionally reach the lower $\mathrm{mg} / \mathrm{kg}$ range. The maximum concentration was about $14,850 \mu \mathrm{g} / \mathrm{kg}$ in a barley sample. Scandinavian results were reported as the sum of different ENN analogues, ENN A, A1, B, B1, B2 and B3, respectively or the analogue was not specified in the presented results $[17,31,32]$. Similar to BEA, contamination levels for ENNs were higher in Moroccan cereals. Maximum concentrations of ENN B1 $(795,000 \mu \mathrm{g} / \mathrm{kg})$, ENN A1 $(688,000 \mu \mathrm{g} / \mathrm{kg})$, ENN A $(119,500 \mu \mathrm{g} / \mathrm{kg})$, and ENN B $(81,100 \mu \mathrm{g} / \mathrm{kg})$ were found in wheat, muesli, rice and oats, respectively [33,34]. In contrast, Moroccan couscous was not contaminated with BEA $(n=98, \mathrm{LOD}=1 \mu \mathrm{g} / \mathrm{kg})$ and ENN concentrations were mostly lower than $100 \mu \mathrm{g} / \mathrm{kg}$ [35].

Concerning feed, the prevalence of BEA ranged between $50 \%$ and $98 \%$, and the observed maximum concentrations were up to $2326 \mu \mathrm{g} / \mathrm{kg}$. Regarding ENNs, feed contamination levels ranged between $<0.1-1745,<0.15-2216,<0.3-1514$ and $<0.2-2690 \mu \mathrm{g} / \mathrm{kg}$, for ENN A, A1, B and B1, respectively (Table 1) [4,38-40]. 
Table 1. Occurrence of emerging Fusarium and Alternaria mycotoxins in food and feed.

\begin{tabular}{|c|c|c|c|c|c|c|}
\hline Commodity & Mycotoxin & $\begin{array}{l}\text { Total \# Samples } \\
\text { Analyzed }\end{array}$ & $\begin{array}{c}\text { Prevalence Range } \\
\text { (\%) }\end{array}$ & $\begin{array}{c}\text { Concentration Range } \\
(\mu \mathrm{g} / \mathrm{kg})\end{array}$ & $\begin{array}{l}\text { Origin of Sample } \\
\text { with Maximum } \\
\text { Concentration }\end{array}$ & Reference \\
\hline \multirow[t]{9}{*}{ Cereals (unprocessed) ${ }^{a}$} & BEA & 482 & $12-100$ & $<10-327$ & Sweden & {$[17,31,32]$} \\
\hline & $\mathrm{ENNs}^{\mathrm{b}}$ & 482 & $96-100$ & & Finland & {$[17,31,32]$} \\
\hline & MON & 590 & $0.88-100$ & $<15-2606$ & Italy & {$[17,31,32,41]$} \\
\hline & $\mathrm{AOH}$ & 1582 & $2.4-47$ & $0.75-832$ & Germany & [42-46] \\
\hline & AME & 1582 & $3.1-7.1$ & $0.3-905$ & Germany & {$[42-46]$} \\
\hline & $\mathrm{TeA}$ & 1526 & $15-68$ & $0.1-4224$ & Germany & {$[42-44]$} \\
\hline & ALT & 1106 & $2.63-7.1$ & 6-196.6 & Germany & {$[42,45]$} \\
\hline & ATX-I & 42 & 2.4 & 43 & South Africa & [45] \\
\hline & TEN & 370 & 77 & $0.4-258.6$ & China & [44] \\
\hline \multirow[t]{5}{*}{ Rice } & BEA & 70 & 75.7 & $3800-26,300$ & Morocco & [34] \\
\hline & ENN A & 70 & 22.8 & $8400-119,500$ & Morocco & [34] \\
\hline & ENN A1 & 70 & 5.7 & $56,200-448,700$ & Morocco & [34] \\
\hline & ENN B & 70 & 30 & $4400-26,200$ & Morocco & [34] \\
\hline & ENN B1 & 70 & 24.3 & $3600-23,700$ & Morocco & [34] \\
\hline \multirow[t]{9}{*}{ Cereal products } & BEA & 354 & $0-17.5$ & $0.1-10,600$ & Morocco & {$[33,35-37]$} \\
\hline & ENN A & 354 & $2.9-77$ & $0.5-29,700$ & Morocco & {$[33,35-37]$} \\
\hline & ENN A1 & 354 & $30-100$ & $0.25-688,000$ & Morocco & {$[33,35-37]$} \\
\hline & ENN B & 354 & $13.2-100$ & $0.5-81,100$ & Morocco & {$[33,35-37]$} \\
\hline & ENN B1 & 354 & $17.6-100$ & $0.5-795,000$ & Morocco & {$[33,35-37]$} \\
\hline & $\mathrm{AOH}$ & 83 & $31-89$ & $8-121$ & Italy & {$[18,36]$} \\
\hline & AME & 83 & $26-89$ & $<0.4-48$ & Italy & {$[18,36]$} \\
\hline & $\mathrm{TeA}$ & 9 & 100 & $<100-210$ & Germany & [18] \\
\hline & TEN & 9 & 100 & $<1.6-12$ & Germany & [18] \\
\hline \multirow[t]{7}{*}{ Tomato products ${ }^{\mathrm{c}}$} & $\mathrm{AOH}$ & 187 & $28-70.6$ & $<2-41.6$ & Belgium & {$[18,19,46,47]$} \\
\hline & AME & 187 & $20-79$ & $<0.9-7.8$ & The Netherlands & {$[18,19,46,47]$} \\
\hline & $\mathrm{TeA}$ & 187 & $40-100$ & $<5-462$ & The Netherlands & {$[18,19,46,47]$} \\
\hline & ALT & 83 & $32-56$ & $6.1-62.0$ & Belgium & [19] \\
\hline & TEN & 117 & $21-64$ & $<3.9-8.9$ & Belgium & {$[18,19]$} \\
\hline & AOH-3-sulfate & 83 & $11-26$ & $2.6-8.7$ & Belgium & [19] \\
\hline & AME-3-sulfate & 83 & $32-78$ & $1.7-9.9$ & Belgium & [19] \\
\hline \multirow[t]{5}{*}{ Fruit juices ${ }^{\mathrm{d}}$} & $\mathrm{AOH}$ & 101 & $15-100$ & $<0.2-16$ & Germany & {$[18,48]$} \\
\hline & AME & 101 & $25-100$ & $<0.13-4.9$ & Germany & {$[18,48]$} \\
\hline & $\mathrm{TeA}$ & 101 & $8-100$ & $<1.1-250$ & Germany & {$[18,48]$} \\
\hline & ALT & 101 & $4.3-100$ & $1.18-18.4$ & Germany & {$[18,48]$} \\
\hline & TEN & 101 & $22-100$ & $<0.5-10.27$ & Germany & {$[18,48]$} \\
\hline
\end{tabular}


Table 1. Cont.

\begin{tabular}{|c|c|c|c|c|c|c|}
\hline Commodity & Mycotoxin & $\begin{array}{l}\text { Total \# Samples } \\
\text { Analyzed }\end{array}$ & $\begin{array}{c}\text { Prevalence Range } \\
(\%)\end{array}$ & $\begin{array}{c}\text { Concentration Range } \\
(\mu \mathrm{g} / \mathrm{kg})\end{array}$ & $\begin{array}{l}\text { Origin of Sample } \\
\text { with Maximum } \\
\text { Concentration }\end{array}$ & Reference \\
\hline & altenuic acid & 78 & 100 & 2.71 & Germany & [48] \\
\hline & altenuisol & 78 & $8-50$ & $<0.74-5.58$ & Germany & [48] \\
\hline Infant food ${ }^{\mathrm{e}}$ & $\mathrm{TeA}$ & 40 & 100 & $0.8-1200$ & Germany & [49] \\
\hline \multirow[t]{6}{*}{ Wines } & $\mathrm{AOH}$ & 30 & $20-93$ & $0.65-11$ & The Netherland & {$[46,48]$} \\
\hline & AME & 25 & 93 & $0.8-1.45$ & Germany & [48] \\
\hline & $\mathrm{TeA}$ & 25 & $60-100$ & $<1-60$ & Germany & [48] \\
\hline & TEN & 25 & 71 & $1.01-1.47$ & Germany & [48] \\
\hline & altenuic acid & 25 & $21-64$ & $<1-6.1$ & Germany & [48] \\
\hline & altenuisol & 25 & $55-71$ & $<0.74-2.91$ & Germany & [48] \\
\hline \multirow[t]{2}{*}{ Dried figs and olives } & $\mathrm{AOH}$ & 14 & 7 & 8.7 & The Netherlands & [47] \\
\hline & $\mathrm{TeA}$ & 19 & $10-100$ & $5.3-2345$ & The Netherlands & {$[46,47]$} \\
\hline \multirow[t]{4}{*}{ Vegetable oil } & $\mathrm{AOH}$ & 19 & 47 & $\leq 6$ & Germany & [18] \\
\hline & AME & 19 & 84 & $<1.1-14$ & Germany & [18] \\
\hline & $\mathrm{TeA}$ & 19 & 21 & 15 & Germany & [18] \\
\hline & TEN & 19 & 47 & $<6.6-11$ & Germany & [18] \\
\hline \multirow[t]{6}{*}{ Sunflower seeds and oils } & $\mathrm{AOH}$ & 35 & $10-55$ & $<4.9-39$ & Germany & {$[18,47]$} \\
\hline & AME & 35 & $9-64$ & $<0.5-17$ & The Netherlands & {$[18,47]$} \\
\hline & TeA & 40 & $80-100$ & $<5-1350$ & The Netherlands & {$[18,46,47]$} \\
\hline & ALT & 11 & 9 & $<14$ & Germany & [18] \\
\hline & ATX-I & 11 & 9 & $<45$ & Germany & [18] \\
\hline & TEN & 16 & $20-91$ & $<3.7-800$ & Germany & {$[18,46]$} \\
\hline \multirow[t]{9}{*}{ Feed } & BEA & 1345 & $50-98$ & $<2-2326$ & not specified & {$[4,38-40]$} \\
\hline & ENN A & 1315 & $0-87$ & $<0.1-1745$ & not specified & {$[4,39,40]$} \\
\hline & ENN A1 & 1315 & $12-95$ & $<0.15-2216$ & not specified & {$[4,39,40]$} \\
\hline & ENN B & 1414 & $28-92$ & $<0.3-1514$ & not specified & {$[4,39,40,50]$} \\
\hline & ENN B1 & 1315 & $12-92$ & $<0.2-1846$ & not specified & {$[4,39,40]$} \\
\hline & MON & 1315 & $3-79$ & $<2-12,236$ & not specified & {$[4,39,40]$} \\
\hline & $\mathrm{AOH}$ & 264 & $0-80$ & $17-221$ & not specified & {$[4,50,51]$} \\
\hline & AME & 264 & $1.5-82$ & $<6-733$ & not specified & {$[4,50,51]$} \\
\hline & TeA & 83 & 65 & not specified-1983 & not specified & [4] \\
\hline
\end{tabular}

${ }^{a}$ Including wheat, oats, barley and rye; ${ }^{b}$ Sum of different ENNs or not specified; ${ }^{c}$ Including tomato sauce, paste, pieces, concentrate, pieces and ketchup; ${ }^{\mathrm{d}}$ Including apple, apricot, carrot, citrus, currant, grape, grapefruit, multi fruit, orange, sour cherry and vitaminized (ACE) juice; ${ }^{\mathrm{e}}$ Including tea infusions, puree infant food and cereals. 


\subsection{Toxicity of Beauvericin and Enniatins}

\subsubsection{In Vitro Toxicity}

The cytotoxic effects of BEA and ENNs have been demonstrated in a variety of cell cultures (Table 2) [5,6,52-56]. The mechanism of toxicity is considered to be related to their ionophoric properties. BEA and ENNs can insert into the cell membrane, forming cation-selective pores and influencing cellular ionic homeostasis. Increased intracellular $\mathrm{Ca}^{2+}$ can trigger cytochrome $\mathrm{C}$ release, which consequently induces an increased caspase- 3 activity, resulting in apoptosis. Furthermore, increased intracellular $\mathrm{Ca}^{2+}$ can also trigger necrosis $[5,6,54,57,58]$. Besides, BEA and ENNs exert their cytotoxic effect through stimulating the production of reactive oxygen species (ROS) resulting in induction of lipid peroxidation (LPO) and glutathione depletion in Caco-2 cells [5,6,58]. Prosperini et al. (2013) demonstrated that ENN A and A1 were more cytotoxic compared to ENN B1 and BEA, while ENN B had the lowest cytotoxic effect in Caco-2 cells. On the other hand, IPEC-J2 cells were more sensitive to ENN B, followed by BEA, ENN B1, ENN A and ENN A1. In Caco-2 cells, ENN A, A1 and B1 induced DNA damage, resulting in a cell cycle arrest at the G2/M phase at concentrations between 1.5 $\mu \mathrm{M}$ and $3.0 \mu \mathrm{M}$. ENN B was not genotoxic in Caco-2 cells. BEA caused cell cycle arrest in the G2/M phase and $S$ phase, presumably as a result of the cellular redox imbalance and at higher concentrations $(12 \mu \mathrm{M})$, BEA caused DNA damage in Caco-2 cells. Above, 2.5-10 $\mu \mathrm{M}$ BEA promoted chromosome aberrations, increased the frequency of sister-chromatid exchanges and induced micronuclei in human lymphocytes (Table 2) [5-7,59].

The neurotoxic and myotoxic effects of BEA were demonstrated in a mouse hemidiaphragm preparation. At low concentrations $(5 \mu \mathrm{M})$, BEA depressed acetylcholine release presynaptically, but at higher concentrations $(7.5$ and $10 \mu \mathrm{M})$, BEA had a direct effect on skeletal muscle fibers, resulting in contractures [60].

Additionally, limited in vitro studies also suggest a toxic effect of BEA and ENNs on the reproductive system (Table 2). BEA impaired the development of cultured porcine oocytes and early embryos. Exposure to BEA resulted in a decreased progesterone synthesis in cumulus cells, reduced MDR1 activity as a consequence of ATP depletion in zygotes and decreased mitochondrial activity in early embryos [61]. Besides, BEA inhibited estradiol and progesterone synthesis in bovine granulosa cells by suppressing CYP19A1 and CYP11A1 gene expression [62]. ENN B also reduced progesterone, testosterone and cortisol secretion in human adrenocortical carcinoma cells (H295R) and modulated the expression of genes involved in steroidogenesis [63].

Furthermore, BEA and ENNs exert immunomodulating effects (Table 2). Ficheux et al. (2013) demonstrated that BEA and ENN B increase IL-10 secretion and affect the initiation of the adaptive immune response by interfering with dendritic cell migration. Moreover, endocytosis by macrophages was decreased after exposure to BEA and ENN B [53]. Besides, ENNs and BEA could also affect health by antimicrobial effects on both pathogenic and probiotic microorganisms. BEA inhibited the growth of pathogenic bacteria, such as Escherichia coli, Enterococcus faecium, Salmonella enterica, Shigella dysenteriae, Listeria monocytogenes, Yersinia enterocolitica, Clostridium perfringens and Pseudomonas aeruginosa [64]. On the other hand, ENN A, A1 and B1 could also inhibit the growth of probiotic microorganisms. Roig et al. (2014) demonstrated the growth inhibition of Streptococcus thermophilus and different strains of the genus Bifidobacterium and Lactobacillus by ENN A1 and ENN B1, while ENN A inhibited Saccharomyces cerevisiae. No impact of ENN B was observed on the growth of different probiotic microorganisms [65]. Further studies on the antimicrobial effects of BEA and ENNs are limited, however, indicating a potential impact on the intestinal microbiota. 
Table 2. In vitro toxicity of emerging Fusarium and Alternaria mycotoxins.

\begin{tabular}{|c|c|c|c|c|c|}
\hline Cell Line & Mycotoxin & Exposure Time & Exposure Dose $(\mu \mathrm{M})$ & Effect & Reference \\
\hline \multirow[t]{17}{*}{$\mathrm{Caco}^{2}{ }^{\mathrm{a}}$} & BEA & $0 \mathrm{~min}$ & 1.5 & ROS $^{\mathrm{b}}$ generation & {$[5,6,56,66,67]$} \\
\hline & & $24-72 \mathrm{~h}$ & & $\mathrm{IC}_{50}: 20.6-3.2 \mu \mathrm{M}\left(\mathrm{MTT}^{\mathrm{c}}\right) ; \mathrm{IC}_{50}: 8.8-1.9 \mu \mathrm{M}\left(\mathrm{NR}^{\mathrm{d}}\right)$ & \\
\hline & & $24-72 \mathrm{~h}$ & $1.5-3.0$ & $\begin{array}{l}\mathrm{LPO}^{\mathrm{e}}, \downarrow \mathrm{GSH}, \uparrow \mathrm{GSSG}, \text { loss of mitochondrial } \\
\text { membrane potential, cell cycle arrest in } \mathrm{S} \text { and G2/M, } \\
\text { apoptosis and necrosis }\end{array}$ & \\
\hline & & $24 \mathrm{~h}$ & 12 & DNA damage & \\
\hline & ENN A & $<1 \mathrm{~h}$ & $1.5-3.0$ & ROS generation & \\
\hline & & $24-72 \mathrm{~h}$ & & $\mathrm{IC}_{50}: 9.3-0.46 \mu \mathrm{M}$ & \\
\hline & & $24-72 \mathrm{~h}$ & $1.5-3.0$ & $\begin{array}{l}\text { LPO, loss of mitochondrial membrane potential, cell } \\
\text { cycle arrest in SubG0/G1 and (Sub)G2/M, DNA } \\
\text { damage, apoptosis and necrosis }\end{array}$ & \\
\hline & ENN A1 & $10 \mathrm{~min}$ & 1.5 & ROS generation & \\
\hline & & $24-72 \mathrm{~h}$ & & $\mathrm{IC}_{50}: 12.3-0.46 \mu \mathrm{M}$ & \\
\hline & & $24-72 \mathrm{~h}$ & $1.5-3.0$ & $\begin{array}{l}\text { LPO, loss of mitochondrial membrane potential, DNA } \\
\text { damage, cell cycle arrest in (Sub)G0/G1 and G2/M, } \\
\text { apoptosis, necrosis }\end{array}$ & \\
\hline & ENN B & $10 \mathrm{~min}$ & 3.0 & ROS generation & \\
\hline & & $48-72 \mathrm{~h}$ & & $\mathrm{IC}_{50}: 10.7-1.4 \mu \mathrm{M}$ & \\
\hline & & $24-72 \mathrm{~h}$ & $1.5-3.0$ & $\begin{array}{l}\text { LPO, loss of mitochondrial membrane potential, cell } \\
\text { cycle arrest in (Sub)G0/G1, and G2/M, apoptosis, } \\
\text { necrosis }\end{array}$ & \\
\hline & ENN B1 & $5-10 \mathrm{~min}$ & $1.5-3.0$ & ROS generation & \\
\hline & & $48-72 \mathrm{~h}$ & & $\mathrm{IC}_{50}: 10.8-0.8 \mu \mathrm{M}$ & \\
\hline & & $24-74 \mathrm{~h}$ & $1.5-3.0$ & $\begin{array}{l}\text { LPO, loss of mitochondrial membrane potential, DNA } \\
\text { damage, cell cycle arrest in (Sub) G0/G1, G2/M and S, } \\
\text { apoptosis, necrosis }\end{array}$ & \\
\hline & $\mathrm{MON}$ & $72 \mathrm{~h}$ & & $\mathrm{IC}_{50}: 30.9 \mu \mathrm{g} / \mathrm{mL}$ & \\
\hline
\end{tabular}


Table 2. Cont.

\begin{tabular}{|c|c|c|c|c|c|}
\hline Cell Line & Mycotoxin & Exposure Time & Exposure Dose $(\mu \mathrm{M})$ & Effect & Reference \\
\hline & $\mathrm{AOH}$ & $24 \mathrm{~h}$ & $15-30$ & $\begin{array}{l}\text { changes in MMP }{ }^{\mathrm{f}}, \downarrow \mathrm{G} 1 \text { phase, } \uparrow \mathrm{S} \text { and } \mathrm{G} 2 / \mathrm{M} \text { phase, } \\
\text { apoptosis, necrosis }\end{array}$ & \\
\hline \multirow[t]{4}{*}{ HT-29 g } & ENN A & $24-48 \mathrm{~h}$ & & $\mathrm{IC}_{50}: 9.3-8.2 \mu \mathrm{M}$ & [56] \\
\hline & ENN A1 & $24-48 \mathrm{~h}$ & & $\mathrm{IC}_{50}: 9.1-1.4 \mu \mathrm{M}$ & \\
\hline & ENN B & $24-48 \mathrm{~h}$ & & $\mathrm{IC}_{50}: \geq 2.8 \mu \mathrm{M}$ & \\
\hline & ENN B1 & $24-48 \mathrm{~h}$ & & $\mathrm{IC}_{50}: 16.8-3.7 \mu \mathrm{M}$ & \\
\hline \multirow[t]{2}{*}{ HCT116 } & $\mathrm{AOH}$ & & & $\begin{array}{l}\mathrm{IC}_{50,24 \mathrm{~h}}: 65 \mu \mathrm{M} \\
\downarrow \text { early apoptotic and late apoptotic/necrotic cells, } \\
\text { ROS generation } \\
\text { PTP }{ }^{\mathrm{h}} \text {-dependent MMP } \\
\text { caspase-cascade activation, activation of p53 protein } \\
\text { expression }\end{array}$ & {$[68,69]$} \\
\hline & AME & & & $\begin{array}{l}\mathrm{IC}_{50,24 \mathrm{~h}}: 120 \mu \mathrm{M} \\
\text { apoptotic cell death, PTP-opening, induction of MMP, } \\
\text { cytochrome c release } \\
\text { caspase-cascade activation, } \uparrow \mathrm{p} 53 \text { protein, ROS } \\
\text { generation }\end{array}$ & \\
\hline \multirow[t]{7}{*}{ IPEC-J $2^{i}$} & BEA & $24-72 \mathrm{~h}$ & $5-10$ & $\begin{array}{l}\text { TEER } \mathrm{j}^{\mathrm{j}} \text { reduction (between }-59 \% \text { and }-80 \% \text { ), no } \\
\text { reduction of cell viability }\end{array}$ & [59] \\
\hline & ENN A & $72 \mathrm{~h}$ & 5 & TEER reduction $(-70 \%)$, no reduction of cell viability & \\
\hline & ENN A1 & $24-72 \mathrm{~h}$ & 10 & $\begin{array}{l}\text { TEER reduction (between }-29 \% \text { and }-74 \% \text { ), no } \\
\text { reduction of cell viability }\end{array}$ & \\
\hline & ENN B & $48-72 \mathrm{~h}$ & 2.5 & $\begin{array}{l}\text { TEER reduction (between }-55 \% \text { and }-68 \% \text { ), no } \\
\text { reduction of cell viability }\end{array}$ & \\
\hline & ENN B1 & $48-72 \mathrm{~h}$ & 5 & $\begin{array}{l}\text { TEER reduction (between }-44 \% \text { and }-58 \% \text { ), no } \\
\text { reduction of cell viability }\end{array}$ & \\
\hline & $\begin{array}{c}\text { ENN } \\
\text { combinations }\end{array}$ & & 1.5 & additive effect on TEER reduction & \\
\hline & MON & $72 \mathrm{~h}$ & $5-10$ & no effect on TEER or viability & [59] \\
\hline
\end{tabular}


Table 2. Cont.

\begin{tabular}{|c|c|c|c|c|c|}
\hline Cell Line & Mycotoxin & Exposure Time & Exposure Dose $(\mu \mathrm{M})$ & Effect & Reference \\
\hline \multirow[t]{5}{*}{ Hep-G2 k } & ENN A & $24-48 \mathrm{~h}$ & & $\mathrm{IC}_{50}: 26.2-11.4 \mu \mathrm{M}$ & {$[56,66]$} \\
\hline & ENN A1 & $24-48 \mathrm{~h}$ & & $\mathrm{IC}_{50}: 11.6-2.6 \mu \mathrm{M}$ & \\
\hline & ENN B & $24-48 \mathrm{~h}$ & & $\mathrm{IC}_{50}:>30 \mu \mathrm{M}$ & \\
\hline & ENN B1 & $24-48 \mathrm{~h}$ & & $\mathrm{IC}_{50}: 24.3-8.5 \mu \mathrm{M}$ & \\
\hline & $\mathrm{MON}$ & $48-72 \mathrm{~h}$ & & $\mathrm{IC}_{50}: 39.5-24.1 \mu \mathrm{g} / \mathrm{mL}$ & \\
\hline \multirow[t]{2}{*}{$\mathrm{H} 295 \mathrm{R}^{1}$} & ENN B & $72 \mathrm{~h}$ & $10-100$ & $\begin{array}{l}\downarrow \text { viability by } 37 \%, \uparrow \text { S-phase, } \downarrow \text { G0/G1phase, } \uparrow \\
\text { apoptosis } \\
\downarrow \text { HMGR, STAR, CYP11A, HSD3B2, CYP17A1 } \\
\uparrow \text { CYP1A1, MC2R, NR0B1, CYP21A2, CYP11B1, } \\
\text { CYP19 } \\
\downarrow \text { progesterone, testosterone and cortisol; estradiol } \\
\text { unaffected }\end{array}$ & {$[63,70,71]$} \\
\hline & $\mathrm{AOH}$ & & 3.87 & $\begin{array}{l}\text { no influence on viability } \\
\uparrow 7 \text { proteins (FDX1, HSD3B, CYP21A2, SCAMP3, } \\
\text { SOAT1, ARF6, RRP15) } \\
\downarrow 15 \text { proteins (ACTBL2, NUCKS1, EIF2B5, COX2, } \\
\text { CRMP1, ABHD14A-ACY1, ATP5J, ACSF2, HN1, } \\
\text { ETHE1, HIST1H1E, ACBD5, NPC1, NR5A1, TOMM7) } \\
\text { upregulation mRNA for CYP21A2 and HSD3B } \\
\uparrow \text { G0/G1 and } \uparrow \text { G2/M phase }\end{array}$ & \\
\hline $\mathrm{H} 29 \mathrm{R}^{1}$ & $\mathrm{AOH}$ & & & $\begin{array}{l}\text { no effect on testosterone and cortisol levels } \\
\uparrow \text { progesterone and estradiol levels } \\
\downarrow N R 0 B 1 \text { gene } \\
\uparrow C Y P 1 A 1, M C 2 R, H S D 3 B 2, C Y P 17, C Y P 21, C Y P 11 B 2, \\
\text { CYP19 }\end{array}$ & {$[72]$} \\
\hline $\begin{array}{l}\text { neonatal Leydig } \\
\text { cells }\end{array}$ & ENN B & & $10-100$ & $\begin{array}{l}\downarrow \text { viability by } 20 \%, \downarrow \text { estradiol in unstimulated cells } \\
\downarrow \text { estradiol and testosterone in LH stimulated cells, } \\
\text { probably due to cytotoxicity }\end{array}$ & [63] \\
\hline $\begin{array}{l}\text { human breast } \\
\text { adenocarcinoma } \\
\text { RGA cell line }\end{array}$ & $\mathrm{AOH}$ & & & $\begin{array}{l}\text { agonistic estrogen response, relative estrogenic } \\
\text { potential: } 0.0004 \% \text { and equivalent estrogenic quantity } \\
\text { of } 17 \beta \text {-estradiol: } 2.9 \mathrm{fg} / \mathrm{mL}\end{array}$ & [72] \\
\hline
\end{tabular}


Table 2. Cont.

\begin{tabular}{|c|c|c|c|c|c|}
\hline Cell Line & Mycotoxin & Exposure Time & Exposure Dose $(\mu \mathrm{M})$ & Effect & Reference \\
\hline cell free buffer & $\mathrm{AOH}$ & & & $\begin{array}{l}\text { binding affinity to } E R \alpha: 10,000 \times \text { lower compared to } \\
17 \beta \text {-estradiol } \\
\text { binding affinity to } E R \beta: 2500 \times \text { lower compared to } \\
17 \beta \text {-estradiol } \\
{\text { similar } E_{50}}\end{array}$ & [73] \\
\hline $\begin{array}{l}\text { Ishikawa human } \\
\text { endometrial } \\
\text { adenocarcinoma } \\
\text { cell line }\end{array}$ & $\mathrm{AOH}$ & & $2.5-10$ & $\begin{array}{l}\uparrow \text { alkaline phosphatase mRNA and activity } \\
\downarrow \text { G1 phase and } \uparrow S \text { and G2/M phase } \\
\downarrow \text { cell number due to inhibition of proliferation }\end{array}$ & [73] \\
\hline $\begin{array}{l}\text { porcine oocytes } \\
\text { and embryos }\end{array}$ & BEA & & $>0.5$ & $\begin{array}{l}\downarrow \text { rate of development of maturing oocyte and } 2-4 \text { cell } \\
\text { stage embryo, activated oocytes and } 2-4 \text { cell stage } \\
\text { embryos more sensitive than maturing oocytes, } \\
\text { compromised cytoplasmic maturation and abnormal } \\
\text { meiosis in oocytes, } \downarrow \text { cumulus viability and } \\
\text { progesterone synthesis, cumulus cells control } \\
\text { intracellular BEA through MDR } 1 \text { activity, in oocytes } \\
\text { mitochondrial function was altered, altered gene } \\
\text { expression in cumulus cells and oocytes, altered } \\
\text { MDR1 activity in activated oocytes, } \downarrow \text { viability embryo }\end{array}$ & [61] \\
\hline \multirow[t]{3}{*}{$\begin{array}{l}\text { pig granulosa } \\
\text { cells }\end{array}$} & $\mathrm{AOH}$ & & $0.8-1.6$ & $\begin{array}{l}\downarrow \text { cell viability, } \downarrow \text { progesterone levels, } \downarrow \text { P450scc } \\
\downarrow \alpha \text {-tubulin, actin and EIF4a }\end{array}$ & [71] \\
\hline & AME & & $0.8-1.6$ & $\downarrow$ cell viability, $\downarrow$ progesterone levels, $\downarrow$ P450scc & \\
\hline & $\mathrm{TeA}$ & & $6.4-100$ & $\begin{array}{l}\text { no influence on viability } \\
\text { no influence on progesterone concentrations }\end{array}$ & \\
\hline \multirow[t]{2}{*}{$\begin{array}{c}\text { bovine } \\
\text { granulosa cells }\end{array}$} & BEA & & 3 & $\begin{array}{l}\downarrow \text { estradiol and progesterone production } \\
\downarrow C Y P 11 A 1 \text { and CYP19A1 mRNA }\end{array}$ & {$[62]$} \\
\hline & & & $6-10$ & $\downarrow$ (fetal calf serum-induced) proliferation & \\
\hline $\mathrm{CHO}-\mathrm{K} 1 \mathrm{~m}$ & BEA & $24-72 \mathrm{~h}$ & & $\begin{array}{l}\mathrm{IC}_{50}: 10.7-2.2 \mu \mathrm{M} \\
\text { combination of BEA + PAT } \mathrm{n}, \mathrm{BEA}+\mathrm{STG}^{\mathrm{o}}, \mathrm{BEA}+ \\
\text { PAT + STG: synergistic effect at low }(\mathrm{IC}<1) \text {, additive } \\
\text { effect at higher (IC } 0.6-5.9) \text { doses }\end{array}$ & {$[52,66,74]$} \\
\hline
\end{tabular}


Table 2. Cont.

\begin{tabular}{|c|c|c|c|c|c|}
\hline Cell Line & Mycotoxin & Exposure Time & Exposure Dose $(\mu \mathrm{M})$ & Effect & Reference \\
\hline & ENN A & $24-72 \mathrm{~h}$ & & $>7.5-2.83 \mu \mathrm{M}$ & \\
\hline & ENN A1 & $24-72 \mathrm{~h}$ & & $8.8-1.65 \mu \mathrm{M}$ & \\
\hline & ENN B & $24-72 \mathrm{~h}$ & & $11.0-2.44 \mu \mathrm{M}$ & \\
\hline & ENN B1 & $24-72 \mathrm{~h}$ & & $4.53-2.47 \mu \mathrm{M}$ & \\
\hline & $\begin{array}{c}\text { ENN } \\
\text { combinations }\end{array}$ & $24 \mathrm{~h}$ & & $\begin{array}{l}\text { additive effects: A + B1, A1 + B, B + B1 } \\
\text { synergistic effects: A + A1, A + B, A1 + B1, A1 + B1, A } \\
+\mathrm{A} 1+\mathrm{B}, \mathrm{A}+\mathrm{A} 1+\mathrm{B} 1, \mathrm{~A} 1+\mathrm{B}+\mathrm{B} 1 \text { (higher } \\
\text { concentrations) } \\
\text { antagonistic effects: } \mathrm{A}+\mathrm{A} 1+\mathrm{B} 1, \mathrm{~A} 1+\mathrm{B}+\mathrm{B} 1 \text { (lower } \\
\text { concentrations) }\end{array}$ & \\
\hline & $\mathrm{MON}$ & & & $\mathrm{IC}_{50}:>100 \mu \mathrm{g} / \mathrm{mL}$ & \\
\hline \multirow[t]{4}{*}{$\begin{array}{l}\text { THP-1 } \mathrm{p} \\
\text { monocyte }\end{array}$} & $\mathrm{AOH}$ & $24-48 \mathrm{~h}$ & $7.5-15$ & cell cycle arrest in S- and G2/M-phase & [55] \\
\hline & & & & $\begin{array}{l}\downarrow \text { CD14 and CD11b upregulation during macrophage } \\
\text { differentiation }\end{array}$ & \\
\hline & & & & $\begin{array}{l}\downarrow \text { downregulation of CD71 during macrophage } \\
\text { differentiation, } \\
\downarrow \text { TNF- } \alpha \text { secretion due to } \downarrow \text { gene expression }\end{array}$ & \\
\hline & & & & $\begin{array}{l}\text { +DON: additive effect } \\
\text { +ZEA: synergistic effect on macrophage differentiation }\end{array}$ & \\
\hline CCRF-CEM q & BEA & $24 \mathrm{~h}$ & 1 & cytotoxicity, apoptosis & {$[54]$} \\
\hline $\begin{array}{l}\text { human } \\
\text { lymphocytes }\end{array}$ & $\mathrm{MON}$ & $48 \mathrm{~h}$ & $\begin{array}{l}10-25 \\
15-25\end{array}$ & $\begin{array}{l}\text { chromosome breaks, chromatid breaks and exchanges, } \\
\text { polyploidy, } \\
\text { increase in sister chromatid exchanges and } \\
\text { micronuclei frequency } \\
\text { all effects were dose-dependent }\end{array}$ & {$[8]$} \\
\hline \multirow{3}{*}{$\begin{array}{l}\text { human } \\
\text { immature } \\
\text { dendritic cells }\end{array}$} & BEA & & & $\mathrm{IC}_{50}: 1.0 \mu \mathrm{M}$ & [53] \\
\hline & ENN B & & & $\mathrm{IC}_{50}: 1.6 \mu \mathrm{M}$ & \\
\hline & $\mathrm{MON}$ & & 80 & $20 \%$ mortality, $\downarrow$ endocytosis, $\downarrow$ CD1a expression & \\
\hline
\end{tabular}


Table 2. Cont.

\begin{tabular}{|c|c|c|c|c|c|}
\hline Cell Line & Mycotoxin & Exposure Time & Exposure Dose $(\mu \mathrm{M})$ & Effect & Reference \\
\hline \multirow{3}{*}{$\begin{array}{l}\text { human mature } \\
\text { dendritic cells }\end{array}$} & BEA & & & $\begin{array}{l}\mathrm{IC}_{50}: 2.9 \mu \mathrm{M}, \downarrow \mathrm{CCR} 7 \text { expression, } \uparrow \mathrm{IL}-10 \\
\text { concentration }\end{array}$ & {$[53]$} \\
\hline & ENN B & & & $\begin{array}{l}\mathrm{IC}_{50}: 2.6 \mu \mathrm{M}, \downarrow \mathrm{CD} 80, \mathrm{CD} 86 \text { and CCR7 expression, } \uparrow \\
\mathrm{IL}-10\end{array}$ & \\
\hline & $\mathrm{MON}$ & & 80 & $20 \%$ mortality & \\
\hline \multirow[t]{4}{*}{$\begin{array}{c}\text { human } \\
\text { macrophages }\end{array}$} & BEA & & $\geq 0.5$ & $\mathrm{IC}_{50}: 2.5 \mu \mathrm{M}, \downarrow$ endocytosis & {$[53,75]$} \\
\hline & ENN B & & & $\mathrm{IC}_{50}: 2.5 \mu \mathrm{M}, \downarrow$ endocytosis,$\uparrow \mathrm{CD} 71$ & \\
\hline & MON & & & $\downarrow$ endocytosis, $\downarrow$ CD71, $\downarrow$ HLA-DR & \\
\hline & $\mathrm{AOH}$ & $24 \mathrm{~h}$ & 30 & $\begin{array}{l}\text { changed morphology: from round to elongated with } \\
\text { dendrite-like protrusions } \\
\uparrow \text { CD83 and CD86 } \\
\downarrow \text { HLA-DR and CD68 } \\
\uparrow \text { secretion of TNF } \alpha \text { and IL- } 6 \\
\downarrow \text { endocytosis and } \downarrow \text { autophagy } \\
\text { double DNA strand breaks }\end{array}$ & \\
\hline $\begin{array}{l}\text { RAW } 2654.7 \\
\text { mouse } \\
\text { macrophage }\end{array}$ & $\mathrm{AOH}$ & $24-48 \mathrm{~h}$ & 30 & $\begin{array}{l}\text { changed morphology: from round to flattened, } \\
\text { star-shaped or elongated spindle-shaped cells } \\
\text { micronuclei, polyploidy, } \uparrow \text { CD86, CD80, MHCII (T cell } \\
\text { activation), } \uparrow \text { CD } 11 b \\
\uparrow \text { mRNA of TNF } \alpha \text { and IL-6, but only } \uparrow \text { TNF } \alpha \\
\text { secretion, } \uparrow \text { endocytosis }\end{array}$ & [75] \\
\hline \multirow[t]{3}{*}{$\begin{array}{l}\text { mouse } \\
\text { hemidiaphragm } \\
\text { preparation }\end{array}$} & BEA & & 5 & $\begin{array}{l}\text { inhibition (in) directly elicited tetanic muscle } \\
\text { contraction; inhibition nerve-evoked and directly } \\
\text { elicited muscle twitches, reduction amplitude and } \\
\text { frequency of miniature endplate potentials }\end{array}$ & {$[60]$} \\
\hline & & $1 \mathrm{~h}$ & 7.5 & $\begin{array}{l}\text { inhibition directly elicited twitches, induction } \\
\text { contracture, decrease resting membrane potential }\end{array}$ & \\
\hline & & $1 \mathrm{~h}$ & 10 & $\begin{array}{l}\text { complete block of (in) directly elicited isometric } \\
\text { muscle contraction, amplitude reduction of directly } \\
\text { elicited muscle twitch, decrease resting membrane } \\
\text { potential }\end{array}$ & \\
\hline
\end{tabular}


Table 2. Cont.

\begin{tabular}{|c|c|c|c|c|c|}
\hline Cell Line & Mycotoxin & Exposure Time & Exposure Dose $(\mu \mathrm{M})$ & Effect & Reference \\
\hline $\mathrm{C} 5-\mathrm{O}^{\mathrm{r}}$ & $\mathrm{MON}$ & $72 \mathrm{~h}$ & & $\mathrm{IC}_{50}: 34.2 \mu \mathrm{g} / \mathrm{mL}$ & [66] \\
\hline V79 s & $\mathrm{MON}$ & $72 \mathrm{~h}$ & & $\mathrm{IC}_{50}:>100 \mu \mathrm{g} / \mathrm{mL}$ & {$[62,66,73]$} \\
\hline & $\mathrm{AOH}$ & & $5-50$ & $\begin{array}{l}\text { induction of micronuclei cell cycle arrest in G2 and S } \\
\text { phase }\end{array}$ & \\
\hline
\end{tabular}

$\downarrow$ decrease; $\uparrow$ increase; ${ }^{a}$ human adenocarcinoma colon cells; ${ }^{\mathrm{b}}$ reactive oxygen species; ${ }^{\mathrm{c}}$ tetrazolium salt reduction assay; ${ }^{\mathrm{d}}$ Neutral Red assay; ${ }^{\mathrm{e}}$ lipid peroxidation; ${ }^{\mathrm{f}}$ mitochondrial membrane permeabilization; ${ }^{g}$ human colon carcinoma cells; ${ }^{\mathrm{h}}$ permeability transition pore; ${ }^{\mathrm{i}}$ intestinal porcine epithelial cells from the jejunum; ${ }^{\mathrm{j}}$ transepithelial electrical resistance; ${ }^{\mathrm{k}}$ human hepatocellular carcinoma cells; ${ }^{1}$ human adrenocortical carcinoma cells; ${ }^{\mathrm{m}}$ Chinese hamster ovary cells; ${ }^{\mathrm{n}}$ patulin; ${ }^{\mathrm{o}}$ sterigmatocystin; ${ }^{\mathrm{p}}$ human acute monocyte leukemia cell line; ${ }^{\mathrm{q}}$ human hepatocellular carcinoma cells; ${ }^{\prime}$ human adrenocortical carcinoma cells; ${ }^{\mathrm{m}}$ Chinese
human leukemia cells; ${ }^{\mathrm{r}}$ Balb $/ \mathrm{c}$ mice keratinocyte cells; ${ }^{\mathrm{s}}$ Chinese hamster lung fibroblast. 


\subsubsection{In Vivo Toxicity}

The in vitro observed immunomodulating effects of BEA and ENNs have been confirmed in rodents. ENN A modulated surface antigen expression of peripheral blood lymphocytes. The number of T-helper $\left(\mathrm{CD}^{+}\right)$cells increased, while cytotoxic T-cells $\left(\mathrm{CD} 8^{+}\right)$decreased in Wistar rats fed an ENN A contaminated feed $(465 \mathrm{mg} / \mathrm{kg})$ for 28 days [76]. BEA decreased serum levels of tumor necrosis factor (TNF-) $\alpha$ and interferon (IFN-) $\gamma$, and induced apoptosis of activated T-cells of mice with experimental colitis after intraperitoneal (ip) administration $(2-4 \mathrm{mg} / \mathrm{kg}$ ) [77]. Fusafungine, a nose and mouth spray consisting of a mixture of ENNs, was used to treat upper airway infections. Mice exposed to fusafungine oral spray, showed low-grade dysplasia, congestion and edema on the tongue, hyperplasia of the cheek mucosa and low-grade dysplasia of the superficial epithelium $[78,79]$. Recently, the European Medicines Agency (EMA) has revoked the authorization of fusafungine sprays, since the benefits do not outweigh the risks, especially the risk of serious allergic reactions [79]. On the other hand, a daily intake of $20.91 \mathrm{mg}$ ENN A/kg bw/day during 28 days did not cause any adverse effects in Wistar rat. The ENN A contaminated diet was obtained through infection with F. tricinctum [80]. However, the EFSA CONTAM Panel concluded that the control and contaminated feed were not comparable due to fungal growth and that there were insufficient details on the detection methods used and on the occurrence of other mycotoxins in the feed to draw conclusions [16].

In vivo toxicity data of BEA and ENNs in livestock and companion animals is limited to poultry. Broiler chickens and laying hens were fed a multi-mycotoxin contaminated diet containing DON

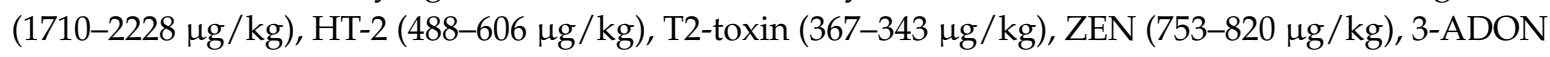
(41-66 $\mu \mathrm{g} / \mathrm{kg}), 15-A D O N(91-227 \mu \mathrm{g} / \mathrm{kg})$, ENN A (28 $\mu \mathrm{g} / \mathrm{kg})$, ENN A1 (491-440 $\mu \mathrm{g} / \mathrm{kg})$, ENN B $(12,716-11,233 \mu \mathrm{g} / \mathrm{kg})$, ENN B1 $(4057-3599 \mu \mathrm{g} / \mathrm{kg})$ and BEA $(10,313-8926 \mu \mathrm{g} / \mathrm{kg})$ for 14 days. No impact on animal performances, such as growth, feed uptake and egg production was observed [81].

Feeding a multi-mycotoxin contaminated diet containing up to $2.7 \mathrm{mg} / \mathrm{kg} \mathrm{MON}$ and up to $12 \mathrm{mg} / \mathrm{kg}$ BEA showed no significant effects on growth or carcass traits of broiler chickens. No residues were detected in the carcass and organs. However, no details on the analytical methods used to determine the concentration of the mycotoxins in the feed, carcass and organs were described. Since no LOQ was reported, no conclusions could be drawn regarding tissue residues. Likewise, growth and slaughter performance were not affected in broilers and turkeys fed a multi-mycotoxin contaminated diet containing both MON and BEA. Contamination levels were as high as $0.5 \mathrm{mg} / \mathrm{kg} \mathrm{MON}$ and $0.8 \mathrm{mg} / \mathrm{kg}$ BEA in broiler feed, and $3.0 \mathrm{mg} / \mathrm{kg}$ MON and $2.48 \mathrm{mg} / \mathrm{kg}$ BEA in turkey feed [16,82].

The EFSA Panel on Contaminants in the Food Chain (CONTAM) identified no-observed-adverse-effect levels (NOAELs) for BEA for broiler chickens $(1220 \mu \mathrm{g} / \mathrm{kg} \mathrm{bw} /$ day), laying hens $(536 \mu \mathrm{g} / \mathrm{kg}$ bw/day) and turkeys (136 $\mu \mathrm{g} / \mathrm{kg}$ bw/day). The identified NOAELs for ENN $\mathrm{B}$ and B1 were 763 and $244 \mu \mathrm{g} / \mathrm{kg}$ bw/day for broiler chickens and 674 and $216 \mu \mathrm{g} / \mathrm{kg}$ bw $/$ day for laying hens [16]. However, a proper risk assessment of chronic toxicity in livestock other than poultry and in companion animals is impossible due to the lack of LOAELs and NOAELs. Furthermore, the EFSA CONTAM panel concluded that the lack of toxicity data precludes a risk assessment for dietary exposure of humans to BEA and ENNs [16].

\subsection{Toxicokinetics of Beauvericin and Enniatins}

Besides exposure and toxicity data, knowledge of toxicokinetics is indispensable for a proper risk assessment, since oral bioavailability, rate of absorption, (pre-)systemic biotransformation, distribution and excretion influence the internal dose of a compound [83]. Toxicokinetic analysis demonstrated the high absolute oral bioavailability ( $\mathrm{F}=90.9 \%)$ of ENN B1 in pigs [20]. In contrast, ENN B1 and ENN B were poorly absorbed after oral administration to broiler chickens, with an $\mathrm{F}$ of $5 \%$ and $11 \%$ for ENN B1 and ENN B, respectively [21]. Both total body clearance $(\mathrm{Cl})$ and volume of distribution $\left(\mathrm{V}_{\mathrm{d}}\right)$ of ENN B1 were higher in broiler chickens compared to pigs. The $\mathrm{Cl}$ of ENN B1 after iv administration was 6.6 $\mathrm{L} / \mathrm{h} / \mathrm{kg}$ and $1.91 \mathrm{~L} / \mathrm{h} / \mathrm{kg}$ in broiler chickens and pigs, respectively. The $\mathrm{V}_{\mathrm{d}}$ of ENN B1 was $25 \mathrm{~L} / \mathrm{kg}$ in broiler chickens. In pigs, the toxicokinetics fitted a two-compartmental model with a $\mathrm{V}_{\mathrm{d}}$ of the 
central and peripheral compartment of 0.57 and $0.69 \mathrm{~L} / \mathrm{kg}$, respectively. The low oral bioavailability and rather high clearance of ENN B and B1 in chickens is in accordance with the EFSA statement that chronic and acute adverse health effects associated with BEA and ENNs in poultry are unlikely [16,21].

Remarkable species differences in oral bioavailability and toxicokinetic parameters could be attributed to differences in biotransformation. Hydroxylated and carboxylated metabolites of ENN B and B1 have been identified in plasma of poultry and pigs. Additionally, carbonylated metabolites of ENN B1 have been detected in pig plasma. Metabolite/ENN B1 ratios were higher after oral, compared to intravenous administration, indicating presystemic metabolism of ENN B1 in pigs. Presystemic metabolism could not be distinguished from systemic metabolism in broiler chickens, due to the low parent and metabolite plasma levels after oral administration $[21,23,84]$. Besides presystemic metabolism, elimination can also occur through efflux into the gut lumen via ATP-binding cassette $(\mathrm{ABC})$ transporters. The major $\mathrm{ABC}$ transporters are P-glycoprotein (P-gp, multidrug resistance protein 1, MDR 1), multidrug resistance-associated protein 2 (MRP 2) and breast cancer resistance protein (BCRP) $[85,86]$. Induction or inhibition of ABC transporters may not only affect oral bioavailability and absorption, but the entire kinetic profile of toxins and drugs, mainly through their effect on hepatic and renal $\mathrm{Cl}$ and $\mathrm{V}_{\mathrm{d}}$ since they are located in these organs as well $[87,88]$. In vitro studies using human cell lines suggest that $A B C$ transporters may play an important role in the absorption of ENNs and BEA, and consequently influencing their oral bioavailability. Ivanova et al. (2010) suggested that P-gp, MRP 2 and BCRP could be involved in the efflux of ENN B1 into the intestinal lumen. Besides, overexpression of BCRP and P-gp resulted in a significant resistance towards the cytotoxic effects of ENNs and BEA in vitro. Above, chronic exposure to stepwise increasing ENN or BEA concentrations resulted in an upregulation of $\mathrm{ABC}$-transporter proteins and cross-resistance to other chemotherapeutics in human cell lines [89]. Interestingly, monensin, an ionophoric coccidiostat which is frequently mixed into poultry feed, can upregulate P-gp expression in the duodenum of broiler chickens $[85,90]$. Therefore, it could be investigated whether feed supplementation with monensin influences the absorption of ENNs and BEA by upregulating the ABC efflux transporters. In addition, ENNs and BEA reduced the intestinal barrier integrity in vitro. Reduced intestinal barrier integrity could not only affect bioavailability of xenobiotics, but could also increase the susceptibility to diseases and reduce performance $[59,89]$. Taken together, the toxicokinetic behavior of these mycotoxins may be complex and can vary between both individuals and species, making species- and compound-specific studies essential.

Data regarding the carry-over of BEA and ENNs in food of animal origin is limited. Finnish eggs were frequently contaminated with BEA and/or ENNs (56-99.7\%). Although levels were low for most of the egg samples, co-contamination of at least two toxins occurred regularly in the yolk samples $(77 \%)$. Both whole egg and yolk samples were most frequently contaminated with ENN B (93-46\% of positive samples) and BEA (7-31\% of positive samples), but ENN A and ENN A1 were only detected in $1 \%$ and $2 \%$ of the positive yolk samples and were not detected in whole egg samples. The higher contamination in yolk, compared to whole eggs, could be attributed to the lipophilic nature of ENNs and BEA [91]. In contrast with the Finnish survey $(n=479$ eggs), neither BEA nor ENNs were detected in commercial eggs $(n=30)$ or in pig meat $(n=10)$ obtained from the Belgian market. In chicken meat samples, only traces of BEA and/or ENNs were detected and ENN B was detected in 4/16 pig liver samples. It should be noted that the number of samples in the Belgian survey was limited and no LOQ was reported for the determination of BEA and ENNs in the different Belgian samples. [16,81]. Callebaut et al. (2011/2012) studied the carry-over of mycotoxins to poultry products by administrating a multi-mycotoxin contaminated diet to both laying hens and broiler chickens. In broiler chickens, traces of ENN A and ENN A1 were only detected in meat, however ENN B, ENN B1 and BEA were detected in meat, liver and skin. Carry-over rates for ENN B and B1 were the highest in skin $(0.39 \%$ and $0.37 \%$, respectively), followed by liver $(0.16 \%$ and $0.12 \%$, respectively), thigh muscle $(0.04 \%)$ and breast muscle $(0.01 \%$ and $0.025 \%$, respectively). Carry-over rate for BEA was highest in liver $(1.57 \%)$, followed by skin $(1.16 \%)$ and muscle $(0.03 \%)$. ENNs and BEA were rapidly eliminated 
from liver and meat, but elimination was slower and incomplete in skin tissue. Regarding eggs, ENN B, B1 and BEA were detected at 2 to 3 days after the contaminated feed was first administrated and reached a maximum at day 5 . It took up to 10 withdrawal days, during which the hens received a control diet, to eliminate ENNs and BEA from the eggs. Carry-over rates were highest for BEA $(0.44 \%)$, followed by ENN B $(0.10 \%)$ and ENN B1 $(0.05 \%)$ [81]. BEA was not detected in milk, sausage, pork or pig liver [38].

\section{Moniliformin}

Moniliformin (MON) or 1-hydroxycyclobut-1-ene-3,4 dion (Figure 2) was first identified as a mycotoxin of F. moniliforme, now referred to as F. verticillioides [92-94]. Besides, MON can also be produced by F. begoniae, F. denticulatum, F. lactis, F. nisikadoi, F. phyllophilum, F. pseudocircinatum, F. pseudonygamai, F. ramigenum, F. tricinctum, F. acutatum, F. anthophilum, F. bulbicola, F. concentricum, F. diaminii, F. fujikuroi, F. napiforme, F. nygamai, F. proliferatum, F. pseudoanthophilum, F. sacchari, F. subglutinans, F. thapsinum, F. beomiforme, F. oxysporum, F. redolens, F. chlamydosporum, F. arthrosporiodes, F. avenaceum and F. acuminatum. Above, Penicillium melanoconidium can also produce MON [30,95-97].

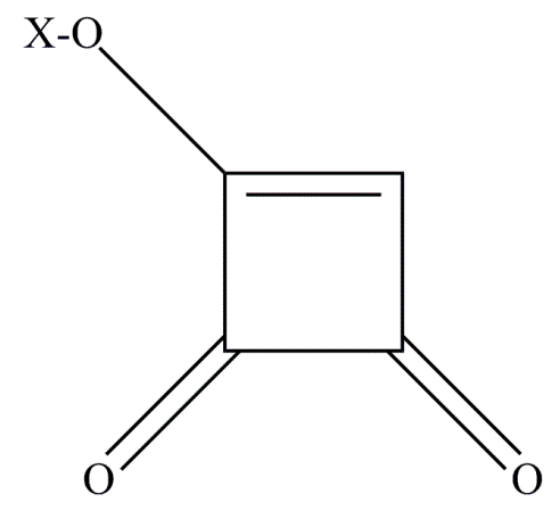

Figure 2. The chemical structure of moniliformin. $\mathrm{X}=\mathrm{H}, \mathrm{Na}$ or $\mathrm{K}$.

\subsection{Occurrence of Moniliformin}

Data on the occurrence of MON in food is limited and summarized in Table 1. In European grain samples, contamination levels ranged between $<15-2606 \mu \mathrm{g} / \mathrm{kg}$ and the prevalence ranged between $0.88-100 \%$. MON levels were usually below $100 \mu \mathrm{g} / \mathrm{kg}$. The maximum MON concentration of $2606 \mu \mathrm{g} / \mathrm{kg}$ was detected in Italian maize. However, a relatively high concentration of MON $(2078 \mu \mathrm{g} / \mathrm{kg})$ was also detected in a Swedish wheat [17,31,32,41].

The prevalence of MON in feed was high, namely $76-79 \%$, as reported by Kovalsky et al. and Streit et al. (2013). In contrast, only 3\% of the Brazilian poultry feed samples was contaminated with MON. Reported maximum concentration from worldwide feed samples was 12,236 $\mu \mathrm{g} / \mathrm{kg}$. [4,39,40].

\subsection{Toxicity of Moniliformin}

The in vitro and in vivo toxic effects of MON are summarized in Tables 2 and 3, respectively. 
Table 3. In vivo toxicity of moniliformin and Alternaria mycotoxins.

\begin{tabular}{|c|c|c|c|c|c|c|}
\hline Animal Species & Mycotoxin & Route of Exposure & Exposure Time & Exposure Dose & Effect & Reference \\
\hline \multirow[t]{2}{*}{ mouse } & $\mathrm{MON}$ & po-ip & $1 \mathrm{x}$ & & $\begin{array}{l}\mathrm{LD}_{50}: 20.9 \text { (\%) } 29.1\left(0^{\top}\right) \mathrm{mg} / \mathrm{kg} \mathrm{bw}(\mathrm{ip}) \text {, } \\
\text { survivors clinically healthy }\end{array}$ & {$[13,92]$} \\
\hline & $\mathrm{TeA}$ & iv-po & $1 \mathrm{x}$ & 0-398 mg/kg bw & $\begin{array}{l}\mathrm{LD}_{50}: 76-162 \text { (iv) and } 81-209(\mathrm{po}) \text {, } \\
\text { vomiting, diarrhea, hemorrhages, death }\end{array}$ & \\
\hline \multirow[t]{5}{*}{ Sprague-Dawley rats } & MON & po & $1 \mathrm{x}$ & $5 \mathrm{mg} / \mathrm{kg} \mathrm{bw}$ & no clinical signs & {$[13,98,99]$} \\
\hline & & & $1 \mathrm{x}$ & $10 \mathrm{mg} / \mathrm{kg} \mathrm{bw}$ & $\begin{array}{l}\downarrow \text { activity for } 24 \mathrm{~h} \text {, respiratory changes, } \\
\text { trembling, piloerection, complete } \\
\text { recovery within } 48 \mathrm{~h}\end{array}$ & \\
\hline & & & $1 \mathrm{x}$ & $25-50 \mathrm{mg} / \mathrm{kg} \mathrm{bw}$ & $\begin{array}{l}\text { respiratory and cardiovascular changes, } \\
\text { collapse, convulsion and death within } \\
48-83 \mathrm{~min}\end{array}$ & \\
\hline & & & 28 days & $3-6 \mathrm{mg} / \mathrm{kg}$ bw & $\begin{array}{l}\text { no clinical symptoms, no effect on } \\
\text { leucocyte and red blood cell counts, } \\
\text { food and water consumption or organ } \\
\text { and body weights, } \downarrow \text { phagocytic activity } \\
\text { of neutrophils }\end{array}$ & \\
\hline & $\mathrm{TeA}$ & iv-po & $1 \mathrm{x}$ & $0-398 \mathrm{mg} / \mathrm{kg}$ bw & $\begin{array}{l}\mathrm{LD}_{50}: 83-157 \text { (iv) and } \mathrm{LD}_{50}: 168-240 \\
\text { (po), vomiting, diarrhea, hemorrhages, } \\
\text { death }\end{array}$ & \\
\hline $\begin{array}{l}\text { Syrian golden } \\
\text { hamster }\end{array}$ & AME & ip & $1 \mathrm{x}$ & $200 \mathrm{mg} / \mathrm{kg}$ bw & $\begin{array}{l}\text { severe necrosis and coalescence of } \\
\text { visceral organs } \\
\text { lethargy, breathing difficulties, flaccid } \\
\text { hind limbs } \uparrow \text { resorptions and } \downarrow \text { fetal } \\
\text { weight }\end{array}$ & [100] \\
\hline \multirow[t]{2}{*}{ chicken embryo } & MON & injection & $1 \mathrm{x}$ & & $\begin{array}{l}\mathrm{LD}_{50}: 2.8 \mu \mathrm{g} / \mathrm{egg} \text {, no gross teratogenic } \\
\text { effects in survivors }\end{array}$ & [92] \\
\hline & $\mathrm{TeA}$ & injection & $1 \mathrm{x}$ & $150-1500 \mu \mathrm{g} / \mathrm{egg}$ & $\begin{array}{l}\text { dose-related mortality, } \mathrm{LD}_{50} \text { : } \\
548 \mu \mathrm{g} / \mathrm{egg}\end{array}$ & [101] \\
\hline 1-day old chicken & $\mathrm{MON}$ & po & $1 \mathrm{x}$ & $0-16 \mathrm{mg} / \mathrm{kg}$ bw & $\begin{array}{l}\mathrm{LD}_{50}: 5.4 \mathrm{mg} / \mathrm{kg} \text { bw (crop intubation), } \\
\text { survivors clinically healthy }\end{array}$ & [92] \\
\hline broiler chickens & MON & feed & 21 days & $200 \mathrm{mg} / \mathrm{kg}$ feed & $\begin{array}{l}\text { death (56\%) } \\
\uparrow \text { kidney, heart and liver weight } \\
\uparrow \text { serum albumin, total protein and } \\
\text { aspartate aminotransferase }\end{array}$ & {$[11,14,102]$} \\
\hline
\end{tabular}


Table 3. Cont.

\begin{tabular}{|c|c|c|c|c|c|c|}
\hline Animal Species & Mycotoxin & Route of Exposure & Exposure Time & Exposure Dose & Effect & Reference \\
\hline & & & & $100 \mathrm{mg} / \mathrm{kg}$ feed & $\begin{array}{l}\downarrow \text { feed intake and body weight gain } \\
\uparrow \text { hearth weight } \\
\uparrow \text { kidney weight if feed also contained } \\
200 \mathrm{mg} \mathrm{FB} / 1 / \mathrm{kg} \\
\uparrow \text { incidence of large pleomorphic } \\
\text { cardiomyocyte nuclei } \\
\text { loss of cardiomyocyte cross striations } \\
\text { mild focal renal tubular mineralization }\end{array}$ & \\
\hline & & feed & 42 days (day $7-49$ ) & $50 \mathrm{mg} / \mathrm{kg}$ feed & $\begin{array}{l}\text { mortality (13.3\%) } \\
\uparrow \text { feed consumption, } \downarrow \text { body weight gain, } \\
\downarrow \text { feed conversion } \\
\uparrow \text { relative heart and proventriculus } \\
\text { weight, } \downarrow \text { mean corpuscular volume } \\
\uparrow \text { serum gamma glutamyltransferase } \\
\text { activity } \\
\text { loss of cardiomyocyte cross striations } \\
\uparrow \text { cardiomyocyte nuclear size }\end{array}$ & \\
\hline & & & & $25 \mathrm{mg} / \mathrm{kg}$ feed & $\begin{array}{l}\text { mortality }(7.8 \%) \\
\uparrow \text { serum gamma glutamyltransferase } \\
\text { activity }\end{array}$ & \\
\hline & $\mathrm{TeA}$ & po & 21 days & $1.25-2.5 \mathrm{mg} / \mathrm{kg}$ bw & $\begin{array}{l}\downarrow \text { weight gain and feed efficiency } \\
\text { hemorrhages, erosions of the gizzard, } \\
\text { pale mottled spleens, edema of the } \\
\text { myocardium, microscopic congestions } \\
\text { of blood vessels and hemorrhages }\end{array}$ & \\
\hline \multirow[t]{3}{*}{$\begin{array}{l}\text { White leghorn } \\
\text { chicken }\end{array}$} & $\mathrm{TeA}$ & po & $1 x$ & & $\begin{array}{l}\mathrm{LD}_{50}: 37.5 \mathrm{mg} / \mathrm{kg} \text { bw with hemorrhages } \\
\text { of the musculature of the thigh, breast, } \\
\text { heart and subcutaneous tissues }\end{array}$ & [14] \\
\hline & & & 21 days & $0.63 \mathrm{mg} / \mathrm{kg}$ bw & $\begin{array}{l}\text { pathological changes in spleen and } \\
\text { gizzard but no extensive hemorrhages } \\
\text { microscopic congestions of blood vessels } \\
\text { and hemorrhages }\end{array}$ & \\
\hline & & & 21 days & $1.25-2.5 \mathrm{mg} / \mathrm{kg} \mathrm{bw}$ & $\begin{array}{l}\downarrow \text { weight gain and feed efficiency } \\
\text { hemorrhages, erosions of the gizzard, } \\
\text { pale mottled spleens, edema of the } \\
\text { myocardium, microscopic congestions } \\
\text { of blood vessels and hemorrhages }\end{array}$ & \\
\hline turkeys & $\mathrm{MON}$ & feed & 91 days (day 7-98) & $\begin{array}{c}25,37.5 \\
50 \mathrm{mg} / \mathrm{kg} \text { feed }\end{array}$ & $\uparrow$ relative heart weight & [102] \\
\hline
\end{tabular}


Table 3. Cont.

\begin{tabular}{|c|c|c|c|c|c|c|}
\hline Animal Species & Mycotoxin & Route of Exposure & Exposure Time & Exposure Dose & Effect & Reference \\
\hline & & & & $37.5,50 \mathrm{mg} / \mathrm{kg}$ feed & $\uparrow$ relative liver weight & \\
\hline & & & & $50 \mathrm{mg} / \mathrm{kg}$ feed & $\begin{array}{l}\text { loss of cardiomyocyte cross striations } \\
\uparrow \text { cardiomyocyte nuclear size, } \uparrow \text { number } \\
\text { of cardiomyocyte mitotic figures }\end{array}$ & \\
\hline turkey poults & $\mathrm{MON}$ & feed & 21-28 days & $100 \mathrm{mg} / \mathrm{kg}$ feed & $\begin{array}{l}\downarrow \text { feed intake, body weight gain, feed } \\
\text { efficiency, } \downarrow \text { relative thymus, bursa and } \\
\text { spleen weights, } \\
\downarrow \text { primary and secondary antibody } \\
\text { response to inactivated Newcastle } \\
\text { disease virus, } \\
\downarrow \text { systemic clearance of } E \text {. coli }\end{array}$ & [103] \\
\hline Japanese quail & $\mathrm{MON}$ & feed & 35 days & $100 \mathrm{mg} / \mathrm{kg}$ feed & $\begin{array}{l}\text { cardiomegaly, myocardial congestion, } \\
\text { hypertrophy, myocardial disarray, } \uparrow \\
\text { mitochondria, resulting in separation of } \\
\text { muscle fibers, swollen and deformed } \\
\text { mitochondria with degenerative } \\
\text { changes. Congestion, hemorrhages and } \\
\text { degenerative changes more pronounced } \\
\text { and extensive disruption of muscle } \\
\text { fibers and destruction of Z-bands when } \\
\text { feed contained both MON and } \\
\text { fumonisin B1. Death. }\end{array}$ & [12] \\
\hline barrow & $\mathrm{MON}$ & feed & 28 days & $100 \mathrm{mg} / \mathrm{kg}$ feed & $\begin{array}{l}\text { acute mortality due to apparent cardiac } \\
\text { failure } \\
\downarrow \text { body weight gain } \\
\downarrow \text { body weight gain, feed consumption } \\
\text { and feed efficiency when feed also } \\
\text { contained } \mathrm{FB}_{1}\end{array}$ & [104] \\
\hline \multirow[t]{3}{*}{$\operatorname{dog}$} & $\mathrm{TeA}$ & iv-po & $1 \mathrm{x}$ & $25-50 \mathrm{mg} / \mathrm{kg}$ bw & $\begin{array}{l}\text { severe tachycardia, massive diffuse } \\
\text { hemorrhages, (bloody) diarrhea }\end{array}$ & [13] \\
\hline & & iv & $3 x$ & $20 \mathrm{mg} / \mathrm{kg} \mathrm{bw}$ & $\begin{array}{l}\text { severe hemorrhagic gastro-enteropathy, } \\
\text { death }\end{array}$ & \\
\hline & & iv-po & 6-30 days & $\begin{array}{c}0.0625-11.2 \mathrm{mg} / \mathrm{kg} \\
\mathrm{bw}\end{array}$ & $\begin{array}{l}\text { salivation, emesis, tachycardia, } \\
\text { hemorrhagic gastro-enteropathy, death }\end{array}$ & \\
\hline \multirow[t]{2}{*}{ monkey } & $\mathrm{TeA}$ & iv & $3 x$ & $20 \mathrm{mg} / \mathrm{kg}$ bw & $\begin{array}{l}\text { severe hemorrhagic gastro-enteropathy, } \\
\text { death }\end{array}$ & [13] \\
\hline & & iv-po & $7-45$ days & $11.2-89.6 \mathrm{mg} / \mathrm{kg}$ & $\begin{array}{l}\text { salivation, emesis, hemorrhagic } \\
\text { gastro-enteropathy, death }\end{array}$ & \\
\hline
\end{tabular}

$\downarrow$ decrease; $\uparrow$ increase. 
MON exerts its toxic effects by inactivating thiamine enzymes, including pyruvate dehydrogenase. Pyruvate dehydrogenase contributes to the formation of acetyl-CoA, which is used in the Krebs cycle. Consequently, MON compromises cellular energy supply [105].

In vitro half maximal inhibitory concentration ( $\mathrm{IC}_{50}$ ) of $\mathrm{MON}$ ranged between 24 and $>100 \mu \mathrm{g} / \mathrm{mL}$ in different cell lines [66]. MON negatively affect immune system by disturbing monocyte differentiation into dendritic cells and macrophages [53]. Furthermore, MON was clastogenic in human lymphocytes and caused chromosomal aberrations, an increase in sister chromatid exchanges and an increase in micronuclei frequency in a dose-dependent manner [8] (Table 2).

MON is strikingly toxic in vivo (Table 3). The heart is the main target organ of MON, causing acute heart failure, but the mycotoxin can also cause muscle weakness, respiratory distress and negatively affect immunity and animal performance $[11,12,98,103,104]$. MON is acutely toxic and has a narrow range of toxicity with an $\mathrm{LD}_{50}$ cut-off value of $25 \mathrm{mg} / \mathrm{kg}$ bw in rats. Similarly, $56 \%$ of the broiler chickens fed a diet contaminated with $200 \mathrm{mg} \mathrm{MON} / \mathrm{kg}$ feed died. Assuming that broilers have a daily feed consumption of $100 \mathrm{~g}$ feed $/ \mathrm{kg}$ bw, the $\mathrm{LD}_{50}$ in poultry and rats is similar [11,98]. A 28-day subacute toxicity study demonstrated that low oral doses of MON (3-6 mg/kg bw) did not cause clinical symptoms in rats. Higher doses caused somnolence and muscle weakness. Two animals in the highest dose group died of acute heart failure. The phagocytic activity of neutrophils was decreased in all treatment groups ( $3-15 \mathrm{mg} / \mathrm{kg}$ bw) even up to 14 days after the last administration, suggesting a prolonged inhibiting effect of MON on the innate immune system [99]. In poultry, chronic dietary exposure to MON negatively influenced the immune response and performance. Cardiotoxicity and hepatotoxicity of MON have been observed in turkeys at contamination levels of $25 \mathrm{mg} / \mathrm{kg}$ and $37.5 \mathrm{mg} / \mathrm{kg}$ feed, respectively. Higher mortality rates, lower feed conversion rates, higher heart and proventriculus weights and heart lesions were observed in broilers fed a MON contaminated diet of $50 \mathrm{mg} \mathrm{MON} / \mathrm{kg}$ feed [102,103]. Similarly, Japanese quails fed a diet containing MON suffered from cardiac lesions (Table 3). When the feed was co-contaminated with fumonisin B1, more severe lesions were observed. Interestingly, a massive increased number of mitochondria was associated with the disruption of heart muscle fibers. This increase of the number of mitochondria could be a compensatory event for the decreased cellular energy, since MON compromises the Krebs cycle [12,105]. It should be noted that the experimental MON levels in the feed studies were about a factor 1000 higher $(50-200 \mathrm{mg} / \mathrm{kg}$ ) than the levels usually found in feed samples ( $\mu \mathrm{g} / \mathrm{kg}$ range). However, high contamination levels (up to $12 \mathrm{mg} / \mathrm{kg}$ ), approaching the hepato- and cardiotoxic levels for poultry (25-50 mg/kg), occasionally occur [4,102].

\subsection{Toxicokinetics of Moniliformin}

The toxicokinetic behavior of MON is largely unknown. MON did not affect intestinal nor blood capillary integrity in vitro. However, in vitro studies suggest that the molecule can pass the blood brain barrier $[59,106]$. After single oral gavage, $42 \%$ of the administered MON was excreted in the urine of rats within $24 \mathrm{~h}$ post administration, and less than $1 \%$ was excreted in the feces. No other toxicokinetic data were reported in this study [98]. To the best of the authors' knowledge, no residue studies of MON in animal-derived products have been described.

\section{Alternaria Mycotoxins}

Alternaria fungi contaminate a wide variety of food and feed crops and produce several toxins, with $\mathrm{AOH}, \mathrm{AME}, \mathrm{TeA}$, altenuene (ALT) and altertoxins (ATXs) being the most important ones [2]. A. alternata and A. arborescens species produce TeA, ALT, AOH and AME. Besides, A. alternata also produces stemphyltoxin III (STTX-III) [107,108]. Furthermore, TeA is also produced by A. bertholletius, A. caelatus, A. nominus, A. pseudonominus, A. arachidicola and A. bombycis [109]. Their chemical structure is presented in Figure 3. 
<smiles>CC[C@H](C)[C@]1(C)C(O)=C(C(C)=O)C(=O)N1[C@H](C)CC</smiles><smiles>O=C1CC[C@]2(O)c3c(ccc(O)c31)-c1ccc(O)c3c1[C@@]2(O)[C@H](O)CC3=O</smiles>

ATX-1<smiles></smiles>

ATX-II

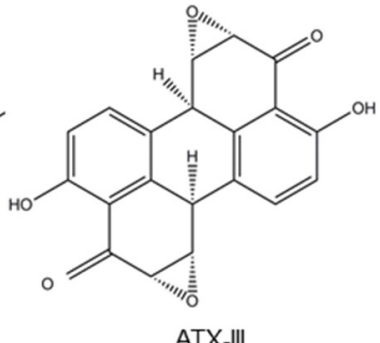

ATX-III<smiles>O=C1C=C[C@]2(O)c3c(ccc(O)c3C1=O)-c1ccc(O)c3c1[C@@H]2[C@@H]1O[C@H]1C3=O</smiles>

STTX-III

Figure 3. Structure of the Alternaria mycotoxins alternariol $(\mathrm{AOH})$, alternariol monomethyl ether (AME), altenuene (ALT), tenuazonic acid (TeA), altertoxins- (ATX-) I, II and III and stemphyltoxin III (STTX-III).

\subsection{Occurrence of Alternaria Mycotoxins}

Contamination of food and feed samples with Alternaria mycotoxins is ubiquitous in grains, fruits, vegetables and wines, as summarized in Table 1. Especially TeA is omnipresent in dried figs, sunflower seeds and tomato products $[18,19,36,42,46-48]$. Grain samples (wheat, maize and cereals) were most frequently contaminated with TeA (15-100\%), followed by TEN (77\%), AOH (2.4-31\%), AME (3-26\%), ALT (2.6-7\%) and ATX-I (2.4\%). For most Alternaria mycotoxins, contamination levels in grains were $<100 \mu \mathrm{g} / \mathrm{kg}$ and maximum concentrations were $<1000 \mu \mathrm{g} / \mathrm{kg}$. However, the maximum observed TeA contamination level in wheat was $4224 \mu \mathrm{g} / \mathrm{kg}[36,42-45]$. The majority of sunflower seeds, collected in retail stores in the Netherlands in 2013-2014, were contaminated with TeA with maximum concentrations of $1400 \mu \mathrm{g} / \mathrm{kg}$. TEN contaminated 20-91\% (maximum concentration of $0.8 \mathrm{mg} / \mathrm{kg}$ ), while AOH and AME were found in 10-64\% of the sunflower seeds at low concentrations $(<50 \mu \mathrm{g} / \mathrm{kg})$. It should be noted that the total number of samples was limited to 15 [46,47]. Although no Alternaria toxins were found in fresh tomatoes, most tomato products were contaminated with at least one Alternaria mycotoxin. TeA was detected in all tomato concentrates and almost all tomato sauces $(78-100 \%)$, pastes $(80 \%)$ and juices $(50-100 \%)$. Furthermore, about half of the tomato pieces $(60 \%)$ and ketchup (40\%) samples were positive for TeA. The maximum TeA levels in tomato products ranged between 100 and $462 \mu \mathrm{g} / \mathrm{kg}$. AOH (28-86\%), AME (20-78\%) and TEN (21-64\%) were also frequently detected in tomato products, but contamination levels were usually as low as a few $\mu \mathrm{g} / \mathrm{kg}$. Plants can metabolise mycotoxins, forming toxins conjugated with sulphates or sugar moieties. The conjugated metabolites, $\mathrm{AOH}-3$-sulfate and AME-3-sulfate, were found in tomato juices, sauces and concentrates in concentrations up to $10 \mu \mathrm{g} / \mathrm{kg}$. Glucosides of $\mathrm{AOH}$ and AME were not detected in figs, sunflower or tomato products $[18,19,46,47]$. Besides, most Alternaria toxins were also detected in fruit juices and wines. Contamination levels were usually a few $\mu \mathrm{g} / \mathrm{L}$. TeA was found in the highest concentrations, namely $250 \mu \mathrm{g} / \mathrm{L}$ in juices, $60 \mu \mathrm{g} / \mathrm{L}$ in white and $46 \mu \mathrm{g} / \mathrm{L}$ in red wine. In contrast, ATX-I and ATX-II were not detected in bakery products, wines, juices or vegetable oils. However, the number of samples was limited, which could be a bias explaining the absence of less frequently occurring toxins $[18,19,48]$. Noteworthy, all infant food products were contaminated with TeA with levels ranging between $0.8-1,200 \mu \mathrm{g} / \mathrm{kg}$. Highest contamination levels were found in sorghum-based infant cereals (mean $550 \mu \mathrm{g} / \mathrm{kg}$ ) [49]. 
Similar to food samples, the prevalence of Alternaria mycotoxins in feed samples varies enormously with contamination levels between $0-80 \%$ for $\mathrm{AOH}$ and $1.5-82 \%$ for AME. Maximum levels were $221 \mu \mathrm{g} / \mathrm{kg}$ and $733 \mu \mathrm{g} / \mathrm{kg}$ for AOH and AME, respectively. Sixty-five percent of feed samples were contaminated with TeA up to $1983 \mu \mathrm{g} / \mathrm{kg}[4,50,51]$.

\subsection{Toxicity of Alternaria Mycotoxins}

The toxicity data of Alternaria toxins are summarized in Tables 2 and 3. AOH and AME are cytotoxic and induce apoptotic cell death through the mitochondrial pathway [67-69]. Recently, the mechanisms of AOH toxicity were reviewed by Solhaug et al. (2016) [110]. AOH forms ROS and interacts with DNA topoisomerase, causing single and double DNA strand breaks. Cell cycle arrest in G2/M-phase, possibly in an attempt to repair the DNA damage, causes a decrease in proliferation. Similarly, AME is also mutagenic and causes DNA strand breaks and cell cycle arrest $[9,10,55,67,68,110,111]$. The quinones ATX-II and STTX-III are much stronger mutagens compared to AOH $[9,10]$. Under cell free conditions, ATX-II, STTX-III and AOH inhibit topoisomerase $\mathrm{II} \alpha$. While $\mathrm{AOH}$ acts as a topoisomerase poison, ATX-II and STTX-III are catalytic inhibitors. AOH, but not ATX-II and STTX-III, causes double DNA strand breaks. It is suggested that ATX-II and STTX-III induce DNA damage through the formation of adducts via epoxide groups [10].

Moreover, $\mathrm{AOH}$ acts immunomodulating in THP-1 monocytes by interfering with macrophage differentiation and decreasing TNF- $\alpha$ secretion. AOH induced morphological changes and modified the phenotype in both RAW 264.7 mouse and primary human macrophages. Endocytic activity and autophagy were increased in RAW 264.7, but decreased in primary human macrophages. Furthermore, RAW 264.7 macrophages entered senescence following prolonged exposure to $\mathrm{AOH}$ $(48-72 \mathrm{~h}, 30-60 \mu \mathrm{M})[55,75,110,112]$.

The dibenzo- $\alpha$-pyrones AOH, AME and ALT structurally resemble estradiol. AOH exhibits an estrogenic response and interferes with steroidogenesis [70,72,73]. Progesterone and estradiol levels and progesterone receptor expression were increased by the estrogenic action of $\mathrm{AOH}$ in human adrenocortical carcinoma cells and transformed human mammary gland cells [72]. In contrast, progesterone secretion and cell viability were negatively affected by both $\mathrm{AOH}$ and $\mathrm{AME}$, but not TeA in porcine granulosa cells. Furthermore, $\mathrm{AOH}$ and AME decreased the abundance of the key enzyme in progesterone synthesis, i.e. P450 cholesterol side-chain cleavage enzyme (P450SCC), but not the corresponding gene transcript (Cyp11a1) [71]. In vivo studies on the effects of Alternaria mycotoxins on reproductive and developmental health are limited. AME (200 mg/kg bw, ip) was maternally toxic and fetotoxic to Syrian golden hamsters, but did not cause teratogenic malformations [100]. In a chicken embryo assay, AOH, AME and ALT did not cause mortality, difference in weight of hatched chicks or teratogenic effects at doses up to 1000; 500 and $1000 \mu \mathrm{g} / \mathrm{egg}$, respectively [101].

TeA exerts its toxic effect through the inhibition of the release of newly formed proteins from the ribosomes [113]. Although in vitro studies are limited, they suggest a low in vitro toxicity of TeA [114]. However, its in vivo effects are more severe. TeA caused emesis, salivation, tachycardia, hemorrhages and hemorrhagic gastro-enteropathy in rats, mice, dogs and monkeys. Similarly, hemorrhages were also observed when feeding broiler chickens and laying hens a diet contaminated with high TeA levels. Oral $\mathrm{LD}_{50}$ of tenuazonic sodium salt ranged between $81-186 \mathrm{mg} / \mathrm{kg}$ bw in mice and rats. In a chicken embryo assay, the $\mathrm{LD}_{50}$ for $\mathrm{TeA}$ was $548 \mu \mathrm{g} / \mathrm{egg}$, but TeA did not cause teratogenic effects at doses ranging between 150 and $1500 \mu \mathrm{g} / \mathrm{egg}[13,14,101]$.

In 2011, EFSA published a scientific opinion on the risks for animal and public health related to the presence of Alternaria toxins in feed and food. A threshold of toxicological concern (TTC) of $2.5 \mathrm{ng} / \mathrm{kg}$ $\mathrm{bw} /$ day was established for AOH and AME. Since there is no evidence of genotoxic action, the TTC for TeA was set at $1500 \mathrm{ng} / \mathrm{kg}$ bw/day. The mean and 95th percentile dietary exposure exceeded the TTC for AOH (factor 16 and 33) and AME (factor 2 and 6), but not for TeA (factor 0.009) [15,18]. Recently, the exceeding of the TTC for AOH and AME, through the consumption of bakery products, juices and tomato products has been confirmed for the German and Belgian population [18,19]. However, 
this EFSA opinion could be considered out of date, since more occurrence data are now available. Especially for TeA, the number of left censored data is decreased and the prevalence of this mycotoxin is high in a variety of food products like wine, figs, grain and tomato products (Table 1). In accordance with the EFSA opinion, both the mean and the 95th percentile dietary exposures via the consumption of tomato products were recently found to be below the TTC for TeA with a factor of 0.07 and 0.5 , respectively [19]. However, TeA not only contaminates tomato products. A more comprehensive study including bakery products, juices, tomato products and sunflower seeds resulted in an 95th percentile dietary exposure exceeding the TTC for TeA, AOH and AME, with a factor 1.4, 12 and 60 respectively [18]. However, it needs to be stressed that for infants the dietary exposure to TeA is estimated to exceed the TTC with a factor of 2.4 due to the high contamination of sorghum $/ \mathrm{millet}$ based cereals [115].

\subsection{Toxicokinetics of Alternaria Mycotoxins}

Fraeyman et al. (2015) demonstrated the complete oral bioavailability of TeA in both pigs and broiler chickens. Furthermore, the total body $\mathrm{Cl}$ of TeA in pigs $(0.45 \mathrm{~L} / \mathrm{h} / \mathrm{kg})$ and broiler chickens $(0.06 \mathrm{~L} / \mathrm{h} / \mathrm{kg})$ was rather low. The low $\mathrm{V}_{\mathrm{d}}$ in both broiler chickens $(0.2 \mathrm{~L} / \mathrm{kg})$ and pigs $(0.3 \mathrm{~L} / \mathrm{kg})$ could indicate a limited tissue distribution. However, especially in broiler chickens, the low $\mathrm{Cl}$ could possibly result in accumulation of TeA when animals are regularly fed a contaminated diet, possibly compromising animal health and elevating the risk for carry-over into the food chain. Therefore, tissue residue studies are recommended [22]. Likewise, the oral bioavailability of TeA is probably also high in humans, since almost $90 \%$ of the ingested dose was recovered in the urine of two volunteers [116]. In contrast, a recent kinetic study in mice suggests a low systemic absorption of $\mathrm{AOH}$, since $90 \%$ of the total dose was excreted via the feces and up to $9 \%$ via the urine [117].

To the best of the authors' knowledge, no data is available regarding carry-over of Alternaria mycotoxins into animal derived products. However, Asam et al. (2013) demonstrated the exposure of humans to TeA through the consumption of animal-derived products, since human urine tested positive for TeA, when the diet was restricted to cheese, milk and milk products [116].

\section{Research Gaps}

Taken together, contamination levels of these emerging Fusarium and Alternaria mycotoxins are usually low ( $\mu \mathrm{g} / \mathrm{kg}$ range). However, higher contamination levels of enniatins and tenuazonic acid may occasionally occur. In vitro studies suggest genotoxic effects of enniatins A, A1 and B1, beauvericin, moniliformin, alternariol, alternariol monomethyl ether, altertoxins and stemphyltoxin-III. Furthermore, in vitro studies suggest immunomodulating effects of most emerging toxins and a reproductive health hazard of alternariol, beauvericin and enniatin B.

As can be concluded from this literature review, there are still remaining knowledge gaps regarding the studied emerging Fusarium and Alternaria toxins in all three key factors for a proper risk assessment, including occurrence, toxicity and toxicokinetic data. Concerning the occurrence data, especially data on emerging toxins in animal-derived products and conjugated Alternaria mycotoxins in different food samples is lacking. An evaluation of the carcinogenic risk of the emerging Fusarium and Alternaria mycotoxins for humans by IARC is advisable. Furthermore, effects on reproductive health and immune system demonstrated in in vitro studies should be verified in vivo. Special attention should be paid to the combinatory effects of emerging mycotoxins and other immunomodulating (e.g., DON or pathogens) and estrogenic (e.g., ZEN or phytoestrogens) substances. Besides, toxicokinetic studies on MON are lacking and toxicokinetics of ENNs, BEA, AOH, AME and TeA are too limited to estimate tissue residues. Therefore, there is a gap between the in vitro toxicity data and the in vivo effect of these mycotoxins. Taking into account new occurrence data for TeA, especially in infant food, the complete oral bioavailability and low total body $\mathrm{Cl}$ in animals and the limited toxicity data, a health risk cannot be completely excluded. Above, several studies indicate a dietary exposure above the TTC of $1500 \mathrm{ng} / \mathrm{kg}$ bw/day $[15,18,115]$. Therefore, a new risk evaluation, including vulnerable 
populations by EFSA may be considered. Besides, the cardiotoxic MON and the possible genotoxic compounds ATXs and STTX-III may be added to the risk evaluation.

Author Contributions: S.F. performed the literature search and wrote the paper. S.C., M.D. and G.A. contributed essential remarks regarding contents and style.

Conflicts of Interest: The authors declare no conflict of interest.

\section{References}

1. Bennett, J.W.; Klich, M. Mycotoxins. Clin. Microbiol. Rev. 2003, 16, 497-516. [CrossRef] [PubMed]

2. Ostry, V. Alternaria mycotoxins: An overview of chemical characterization, producers, toxicity, analysis and occurrence in foodstuffs. World Mycotoxin J. 2008, 1, 175-188. [CrossRef]

3. Sulyok, M.; Krska, R.; Schuhmacher, R. A liquid chromatography/tandem mass spectrometric multi-mycotoxin method for the quantification of 87 analytes and its application to semi-quantitative screening of moldy food samples. Anal. Bioanal. Chem. 2007, 389, 1505-1523. [CrossRef] [PubMed]

4. Streit, E.; Schwab, C.; Sulyok, M.; Naehrer, K.; Krska, R.; Schatzmayr, G. Multi-mycotoxin screening reveals the occurrence of 139 different secondary metabolites in feed and feed ingredients. Toxins 2013, 5, 504-523. [CrossRef] [PubMed]

5. Prosperini, A.; Juan-García, A.; Font, G.; Ruiz, M.J. Beauvericin-induced cytotoxicity via ROS production and mitochondrial damage in Caco-2 cells. Toxicol. Lett. 2013, 222, 204-211. [CrossRef] [PubMed]

6. Prosperini, A.; Juan-García, A.; Font, G.; Ruiz, M.J. Reactive oxygen species involvement in apoptosis and mitochondrial damage in Caco-2 cells induced by enniatins a, a(1), b and b(1). Toxicol. Lett. 2013, 222, 36-44. [CrossRef] [PubMed]

7. Çelik, M.; Aksoy, H.; Yilmaz, S. Evaluation of beauvericin genotoxicity with the chromosomal aberrations, sister-chromatid exchanges and micronucleus assays. Ecotoxicol. Environ. Saf. 2010, 73, 1553-1557. [CrossRef] [PubMed]

8. Çelik, M.; Yilmaz, S.; Aksoy, H.; Unal, F.; Yuzbasioglu, D.; Donbak, L. Evaluation of the genotoxicity of Fusarium mycotoxin moniliformin in human peripheral blood lymphocytes. Environ. Mol. Mutagen. 2009, 50, 431-434. [CrossRef] [PubMed]

9. Fleck, S.C.; Burkhardt, B.; Pfeiffer, E.; Metzler, M. Alternaria toxins: Altertoxin II is a much stronger mutagen and DNA strand breaking mycotoxin than alternariol and its methyl ether in cultured mammalian cells. Toxicol. Lett. 2012, 214, 27-32. [CrossRef] [PubMed]

10. Fleck, S.C.; Sauter, F.; Pfeiffer, E.; Metzler, M.; Hartwig, A.; Köberle, B. DNA damage and repair kinetics of the Alternaria mycotoxins alternariol, altertoxin II and stemphyltoxin III in cultured cells. Mutat. Res. Genet. Toxicol. Environ. Mutagen. 2016, 798-799, 27-34. [CrossRef] [PubMed]

11. Ledoux, D.R.; Broomhead, J.N.; Bermudez, A.J.; Rottinghaus, G.E. Individual and combined effects of the Fusarium mycotoxins fumonisin b1 and moniliformin in broiler chicks. Avian Dis. 2003, 47, 1368-1375. [CrossRef] [PubMed]

12. Sharma, D.; Asrani, R.K.; Ledoux, D.R.; Rottinghaus, G.E.; Gupta, V.K. Toxic interaction between fumonisin b-1 and moniliformin for cardiac lesions in Japanese quail. Avian Dis. 2012, 56, 545-554. [CrossRef] [PubMed]

13. Smith, E.R.; Fredrickson, T.N.; Hadidian, Z. Toxic effects of the sodium and the n, $\mathrm{n}^{\prime}$-dibenzylethylenediamine salts of tenuazonic acid (nsc-525816 and nsc-82260). Cancer Chemother. Rep. 1968, 52, 579-585. [PubMed]

14. Giambrone, J.J.; Davis, N.D.; Diener, U.L. Effect of tenuazonic acid on young chickens. Poult. Sci. 1978, 57, 1554-1558. [CrossRef] [PubMed]

15. EFSA. Scientific opinion on the risks for animal and public health related to the presence of Alternaria toxins in food and feed. EFSA J. 2011, 9, 97. [CrossRef]

16. EFSA. Scientific opinion on the risks to human and animal health related to the presence of beauvericin and enniatins in food and feed. EFSA J. 2014, 12, 174. [CrossRef]

17. Hietaniemi, V.; Rämö, S.; Yli-Mattila, T.; Jestoi, M.; Peltonen, S.; Kartio, M.; Sieviläinen, E.; Koivisto, T.; Parikka, P. Updated survey of Fusarium species and toxins in Finnish cereal grains. Food Addit. Contam. Part A Chem. Anal. Control Expo. Risk Assess. 2016, 33, 831-848. [CrossRef] [PubMed] 
18. Hickert, S.; Bergmann, M.; Ersen, S.; Cramer, B.; Humpf, H.U. Survey of Alternaria toxin contamination in food from the German market, using a rapid HPLC-MS/MS approach. Mycotoxin Res. 2016, 32, 7-18. [CrossRef] [PubMed]

19. Walravens, J.; Mikula, H.; Rychlik, M.; Asam, S.; Devos, T.; Ediage, E.N.; Di Mavungu, J.D.; Jacxsens, L.; Van Landschoot, A.; Vanhaecke, L.; et al. Validated UPLC-MS/MS methods to quantitate free and conjugated Alternaria toxins in commercially available tomato products and fruit and vegetable juices in Belgium. J. Agric. Food Chem. 2016, 64, 5101-5109. [CrossRef] [PubMed]

20. Devreese, M.; Broekaert, N.; De Mil, T.; Fraeyman, S.; De Backer, P.; Croubels, S. Pilot toxicokinetic study and absolute oral bioavailability of the Fusarium mycotoxin enniatin b1 in pigs. Food Chem. Toxicol. 2014, 63, 161-165. [CrossRef] [PubMed]

21. Fraeyman, S.; Devreese, M.; Antonissen, G.; De Baere, S.; Rychlik, M.; Croubels, S. Comparative oral bioavailability, toxicokinetics, and biotransformation of enniatin b1 and enniatin b in broiler chickens. J. Agric. Food Chem. 2016, 64, 7259-7264. [CrossRef] [PubMed]

22. Fraeyman, S.; Devreese, M.; Broekaert, N.; De Mil, T.; Antonissen, G.; De Baere, S.; De Backer, P.; Rychlik, M.; Croubels, S. Quantitative determination of tenuazonic acid in pig and broiler chicken plasma by LC-MS/MS and its comparative toxicokinetics. J. Agric. Food Chem. 2015, 63, 8560-8567. [CrossRef] [PubMed]

23. Ivanova, L.; Uhlig, S.; Devreese, M.; Croubels, S.; Faeste, C.K. Biotransformation of the mycotoxin enniatin b1 in pigs: A comparative in vitro and in vivo approach. Food Chem. Toxicol. Int. J. Publ. Br. Ind. Biol. Res. Assoc. 2017, 105, 506-517. [CrossRef] [PubMed]

24. Gruber-Dorninger, C.; Novak, B.; Nagl, V.; Berthiller, F. Emerging mycotoxins: Beyond traditionally determined food contaminants. J. Agric. Food Chem. 2016. [CrossRef] [PubMed]

25. Hamill, R.L.; Higgens, C.E.; Boaz, H.E.; Gorman, M. Structure of beauvericin, a new depsipeptide antibiotic toxic to artemia salina. Tetrahedron Lett. 1969, 10, 4255-4258. [CrossRef]

26. Thrane, U.; Adler, A.; Clasen, P.E.; Galvano, F.; Langseth, W.; Lew, H.; Logrieco, A.; Nielsen, K.F.; Ritieni, A. Diversity in metabolite production by Fusarium langsethiae, Fusarium poae, and Fusarium sporotrichioides. Int. J. Food Microbiol. 2004, 95, 257-266. [CrossRef] [PubMed]

27. Logrieco, A.; Moretti, A.; Castella, G.; Kostecki, M.; Golinski, P.; Ritieni, A.; Chelkowski, J. Beauvericin production by Fusarium species. Appl. Environ. Microbiol. 1998, 64, 3084-3088. [PubMed]

28. Logrieco, A.; Rizzo, A.; Ferracane, R.; Ritieni, A. Occurrence of beauvericin and enniatins in wheat affected by Fusarium avenaceum head blight. Appl. Environ. Microbiol. 2002, 68, 82-85. [CrossRef] [PubMed]

29. Herrmann, M.; Zocher, R.; Haese, A. Enniatin production by Fusarium strains and its effect on potato tuber tissue. Appl. Environ. Microbiol. 1996, 62, 393-398. [PubMed]

30. Christ, D.S.; Godecke, R.; von Tiedemann, A.; Varrelmann, M. Pathogenicity, symptom development, and mycotoxin formation in wheat by Fusarium species frequently isolated from sugar beet. Phytopathology 2011, 101, 1338-1345. [CrossRef] [PubMed]

31. Lindblad, M.; Gidlund, A.; Sulyok, M.; Borjesson, T.; Krska, R.; Olsen, M.; Fredlund, E. Deoxynivalenol and other selected Fusarium toxins in Swedish wheat-Occurrence and correlation to specific Fusarium species. Int. J. Food Microbiol. 2013, 167, 284-291. [CrossRef] [PubMed]

32. Fredlund, E.; Gidlund, A.; Sulyok, M.; Börjesson, T.; Krska, R.; Olsen, M.; Lindblad, M. Deoxynivalenol and other selected Fusarium toxins in Swedish oats-Occurrence and correlation to specific Fusarium species. Int. J. Food. Microbiol. 2013, 167, 276-283. [CrossRef] [PubMed]

33. Mahnine, N.; Meca, G.; Elabidi, A.; Fekhaoui, M.; Saoiabi, A.; Font, G.; Manes, J.; Zinedine, A. Further data on the levels of emerging Fusarium mycotoxins enniatins (a, a1, b, b1), beauvericin and fusaproliferin in breakfast and infant cereals from Morocco. Food Chem. 2011, 124, 481-485. [CrossRef]

34. Sifou, A.; Meca, G.; Serrano, A.B.; Mahnine, N.; El Abidi, A.; Manes, J.; El Azzouzi, M.; Zinedine, A. First report on the presence of emerging Fusarium mycotoxins enniatins (a, a-1, b, b-1), beauvericin and fusaproliferin in rice on the Moroccan retail markets. Food Control 2011, 22, 1826-1830. [CrossRef]

35. Zinedine, A.; Fernandez-Franzon, M.; Manes, J.; Manyes, L. Multi-mycotoxin contamination of couscous semolina commercialized in Morocco. Food Chem. 2017, 214, 440-446. [CrossRef] [PubMed]

36. Juan, C.; Covarelli, L.; Beccari, G.; Colasante, V.; Manes, J. Simultaneous analysis of twenty-six mycotoxins in durum wheat grain from Italy. Food Control 2016, 62, 322-329. [CrossRef] 
37. Serrano, A.B.; Font, G.; Manes, J.; Ferrer, E. Emerging Fusarium mycotoxins in organic and conventional pasta collected in Spain. Food Chem. Toxicol. Int. J. Publ. Br. Ind. Biol. Res. Assoc. 2013, 51, 259-266. [CrossRef] [PubMed]

38. Zhao, Z.; Liu, N.; Yang, L.; Deng, Y.; Wang, J.; Song, S.; Lin, S.; Wu, A.; Zhou, Z.; Hou, J. Multi-mycotoxin analysis of animal feed and animal-derived food using LC-MS/MS system with timed and highly selective reaction monitoring. Anal. Bioanal. Chem. 2015, 407, 7359-7368. [CrossRef] [PubMed]

39. Kovalsky, P.; Kos, G.; Nahrer, K.; Schwab, C.; Jenkins, T.; Schatzmayr, G.; Sulyok, M.; Krska, R. Co-occurrence of regulated, masked and emerging mycotoxins and secondary metabolites in finished feed and maize-an extensive survey. Toxins 2016, 8, 363. [CrossRef] [PubMed]

40. De Lourdes Mendes de Souza, M.; Sulyok, M.; Freitas-Silva, O.; Costa, S.S.; Brabet, C.; Machinski Junior, M.; Sekiyama, B.L.; Vargas, E.A.; Krska, R.; Schuhmacher, R. Cooccurrence of mycotoxins in maize and poultry feeds from brazil by liquid chromatography/tandem mass spectrometry. Sci. World J. 2013, 2013, 427369. [CrossRef]

41. Scarpino, V.; Blandino, M.; Negre, M.; Reyneri, A.; Vanara, F. Moniliformin analysis in maize samples from north-west Italy using multifunctional clean-up columns and the LC-MS/MS detection method. Food Addit. Contam. Part A Chem. Anal. Control Expo. Risk Assess. 2013, 30, 876-884. [CrossRef] [PubMed]

42. Müller, M.E.H.; Korn, U. Alternaria mycotoxins in wheat-A 10 years survey in the northeast of Germany. Food Control 2013, 34, 191-197. [CrossRef]

43. Janić Hajnal, E.; Orčić, D.; Torbica, A.; Kos, J.; Mastilović, J.; Škrinjar, M. Alternaria toxins in wheat from the autonomous province of Vojvodina, Serbia: A preliminary survey. Food Addit. Contam. Part A Chem. Anal. Control Expo. Risk Assess. 2015, 32, 361-370. [CrossRef] [PubMed]

44. Xu, W.J.; Han, X.M.; Li, F.Q.; Zhang, L.S. Natural occurrence of alternaria toxins in the 2015 wheat from Anhui province, China. Toxins 2016, 8, 308. [CrossRef] [PubMed]

45. Hickert, S.; Gerding, J.; Ncube, E.; Hubner, F.; Flett, B.; Cramer, B.; Humpf, H.U. A new approach using micro HPLC-MS/MS for multi-mycotoxin analysis in maize samples. Mycotoxin Res. 2015, 31, 109-115. [CrossRef] [PubMed]

46. López, P.; Venema, D.; de Rijk, T.; de Kok, A.; Scholten, J.M.; Mol, H.G.J.; de Nijs, M. Occurrence of Alternaria toxins in food products in the Netherlands. Food Control 2016, 60, 196-204. [CrossRef]

47. López, P.; Venema, D.; Mol, H.; Spanjer, M.; de Stoppelaar, J.; Pfeiffer, E.; de Nijs, M. Alternaria toxins and conjugates in selected foods in the Netherlands. Food Control 2016, 69, 153-159. [CrossRef]

48. Zwickel, T.; Klaffke, H.; Richards, K.; Rychlik, M. Development of a high performance liquid chromatography tandem mass spectrometry based analysis for the simultaneous quantification of various Alternaria toxins in wine, vegetable juices and fruit juices. J. Chromatogr. A 2016, 1455, 74-85. [CrossRef] [PubMed]

49. Asam, S.; Rychlik, M. Potential health hazards due to the occurrence of the mycotoxin tenuazonic acid in infant food. Eur. Food Res. Technol. 2013, 236, 491-497. [CrossRef]

50. Storm, I.M.; Rasmussen, R.R.; Rasmussen, P.H. Occurrence of pre- and post-harvest mycotoxins and other secondary metabolites in Danish maize silage. Toxins (Basel) 2014, 6, 2256-2269. [CrossRef] [PubMed]

51. Monbaliu, S.; Van Poucke, C.; Detavernier, C.; Dumoulin, F.; Van De Velde, M.; Schoeters, E.; Van Dyck, S.; Averkieva, O.; Van Peteghem, C.; De Saeger, S. Occurrence of mycotoxins in feed as analyzed by a multi-mycotoxin LC-MS/MS method. J. Agric. Food Chem. 2010, 58, 66-71. [CrossRef] [PubMed]

52. Zouaoui, N.; Mallebrera, B.; Berrada, H.; Abid-Essefi, S.; Bacha, H.; Ruiz, M.J. Cytotoxic effects induced by patulin, sterigmatocystin and beauvericin on CHO-K1 cells. Food Chem. Toxicol. Int. J. Publ. Br. Ind. Biol. Res. Assoc. 2016, 89, 92-103. [CrossRef] [PubMed]

53. Ficheux, A.S.; Sibiril, Y.; Parent-Massin, D. Effects of beauvericin, enniatin b and moniliformin on human dendritic cells and macrophages: An in vitro study. Toxicon 2013, 71, 1-10. [CrossRef] [PubMed]

54. Jow, G.M.; Chou, C.J.; Chen, B.F.; Tsai, J.H. Beauvericin induces cytotoxic effects in human acute lymphoblastic leukemia cells through cytochrome c release, caspase 3 activation: The causative role of calcium. Cancer Lett. 2004, 216, 165-173. [CrossRef] [PubMed]

55. Solhaug, A.; Karlsøen, L.M.; Holme, J.A.; Kristoffersen, A.B.; Eriksen, G.S. Immunomodulatory effects of individual and combined mycotoxins in the THP-1 cell line. Toxicol. In Vitro 2016, 36, 120-132. [CrossRef] [PubMed] 
56. Meca, G.; Font, G.; Ruiz, M.J. Comparative cytotoxicity study of enniatins a, a(1), a(2), b, b(1), b(4) and j(3) on Caco-2 cells, Hep-G(2) and HT-29. Food Chem. Toxicol. Int. J. Publ. Br. Ind. Biol. Res. Assoc. 2011, 49, 2464-2469. [CrossRef] [PubMed]

57. Kamyar, M.; Rawnduzi, P.; Studenik, C.R.; Kouri, K.; Lemmens-Gruber, R. Investigation of the electrophysiological properties of enniatins. Arch. Biochem. Biophys. 2004, 429, 215-223. [CrossRef] [PubMed]

58. Kouri, K.; Lemmens, M.; Lemmens-Gruber, R. Beauvericin-induced channels in ventricular myocytes and liposomes. Biochim. Biophys. Acta 2003, 1609, 203-210. [CrossRef]

59. Springler, A.; Vrubel, G.J.; Mayer, E.; Schatzmayr, G.; Novak, B. Effect of Fusarium-derived metabolites on the barrier integrity of differentiated intestinal porcine epithelial cells (IPEC-J2). Toxins (Basel) 2016, 8, E345. [CrossRef] [PubMed]

60. Žužek, M.C.; Grandič, M.; Jakovac Strajn, B.; Frangež, R. Beauvericin inhibits neuromuscular transmission and skeletal muscle contractility in mouse hemidiaphragm preparation. Toxicol. Sci. 2016, 150, $283-291$. [CrossRef] [PubMed]

61. Schoevers, E.J.; Santos, R.R.; Fink-Gremmels, J.; Roelen, B.A. Toxicity of beauvericin on porcine oocyte maturation and preimplantation embryo development. Reprod. Toxicol. 2016, 65, 159-169. [CrossRef] [PubMed]

62. Albonico, M.; Schutz, L.F.; Caloni, F.; Cortinovis, C.; Spicer, L.J. In vitro effects of the Fusarium mycotoxins fumonisin b1 and beauvericin on bovine granulosa cell proliferation and steroid production. Toxicon 2017, 128, 38-45. [CrossRef] [PubMed]

63. Kalayou, S.; Ndossi, D.; Frizzell, C.; Groseth, P.K.; Connolly, L.; Sørlie, M.; Verhaegen, S.; Ropstad, E. An investigation of the endocrine disrupting potential of enniatin b using in vitro bioassays. Toxicol. Lett. 2015, 233, 84-94. [CrossRef] [PubMed]

64. Meca, G.; Sospedra, I.; Soriano, J.M.; Ritieni, A.; Moretti, A.; Manes, J. Antibacterial effect of the bioactive compound beauvericin produced by Fusarium proliferatum on solid medium of wheat. Toxicon 2010, 56, 349-354. [CrossRef] [PubMed]

65. Roig, M.; Meca, G.; Marin, R.; Ferrer, E.; Manes, J. Antibacterial activity of the emerging Fusarium mycotoxins enniatins a, a(1), a(2), b, b-1, and b-4 on probiotic microorganisms. Toxicon 2014, 85, 1-4. [CrossRef] [PubMed]

66. Cetin, Y.; Bullerman, L.B. Cytotoxicity of Fusarium mycotoxins to mammalian cell cultures as determined by the mtt bioassay. Food Chem. Toxicol. Int. J. Publ. Br. Ind. Biol. Res. Assoc. 2005, 43, 755-764. [CrossRef] [PubMed]

67. Fernández-Blanco, C.; Juan-García, A.; Juan, C.; Font, G.; Ruiz, M.J. Alternariol induce toxicity via cell death and mitochondrial damage on Caco-2 cells. Food Chem. Toxicol. 2016, 88, 32-39. [CrossRef] [PubMed]

68. Bensassi, F.; Gallerne, C.; El Dein, O.S.; Hajlaoui, M.R.; Bacha, H.; Lemaire, C. Cell death induced by the Alternaria mycotoxin alternariol. Toxicol. In Vitro 2012, 26, 915-923. [CrossRef] [PubMed]

69. Bensassi, F.; Gallerne, C.; El Dein, O.S.; Hajlaoui, M.R.; Bacha, H.; Lemaire, C. Mechanism of alternariol monomethyl ether-induced mitochondrial apoptosis in human colon carcinoma cells. Toxicology 2011, 290, 230-240. [CrossRef] [PubMed]

70. Kalayou, S.; Hamre, A.G.; Ndossi, D.; Connolly, L.; Sørlie, M.; Ropstad, E.; Verhaegen, S. Using SILAC proteomics to investigate the effect of the mycotoxin, alternariol, in the human H295R steroidogenesis model. Cell Biol. Toxicol. 2014, 30, 361-376. [CrossRef] [PubMed]

71. Tiemann, U.; Tomek, W.; Schneider, F.; Müller, M.; Pöhland, R.; Vanselow, J. The mycotoxins alternariol and alternariol methyl ether negatively affect progesterone synthesis in porcine granulosa cells in vitro. Toxicol. Lett. 2009, 186, 139-145. [CrossRef] [PubMed]

72. Frizzell, C.; Ndossi, D.; Kalayou, S.; Eriksen, G.S.; Verhaegen, S.; Sørlie, M.; Elliott, C.T.; Ropstad, E.; Connolly, L. An in vitro investigation of endocrine disrupting effects of the mycotoxin alternariol. Toxicol. Appl. Pharmacol. 2013, 271, 64-71. [CrossRef] [PubMed]

73. Lehmann, L.; Wagner, J.; Metzler, M. Estrogenic and clastogenic potential of the mycotoxin alternariol in cultured mammalian cells. Food Chem. Toxicol. Int. J. Publ. Br. Ind. Biol. Res. Assoc. 2006, 44, 398-408. [CrossRef] [PubMed]

74. Lu, H.; Fernández-Franzón, M.; Font, G.; Ruiz, M.J. Toxicity evaluation of individual and mixed enniatins using an in vitro method with CHO-K1 cells. Toxicol. In Vitro 2013, 27, 672-680. [CrossRef] [PubMed] 
75. Solhaug, A.; Wisbech, C.; Christoffersen, T.E.; Hult, L.O.; Lea, T.; Eriksen, G.S.; Holme, J.A. The mycotoxin alternariol induces DNA damage and modify macrophage phenotype and inflammatory responses. Toxicol. Lett. 2015, 239, 9-21. [CrossRef] [PubMed]

76. Juan, C.; Manyes, L.; Font, G.; Juan-Garcia, A. Evaluation of immunologic effect of enniatin a and quantitative determination in feces, urine and serum on treated wistar rats. Toxicon 2014, 87, 45-53. [CrossRef] [PubMed]

77. Wu, X.F.; Xu, R.; Ouyang, Z.J.; Qian, C.; Shen, Y.; Wu, X.D.; Gu, Y.H.; Xu, Q.; Sun, Y. Beauvericin ameliorates experimental colitis by inhibiting activated $\mathrm{T}$ cells via downregulation of the pi3k/akt signaling pathway. PLOS ONE 2013, 8, e83013. [CrossRef] [PubMed]

78. Yuca, K.; Cankaya, H.; Bayram, W.; Ozbek, H.; Kiris, M. Local irritant effects of topical oral sprays on oral mucosa in mice. Adv. Ther. 2006, 23, 98-106. [CrossRef] [PubMed]

79. EMA. Cmdh Endorses Revocation of Authorisations for Fusafungine Sprays Used to Treat Airway Infections; EMA/227560/2016; European Medicine Agency: London, UK, 2016.

80. Manyes, L.; Escrivá, L.; Serrano, A.B.; Rodríguez-Carrasco, Y.; Tolosa, J.; Meca, G.; Font, G. A preliminary study in wistar rats with enniatin a contaminated feed. Toxicol. Mech. Methods 2014, 24, 179-190. [CrossRef] [PubMed]

81. Callebaut, F.; Tangni, E.K.; Debongnie, P.; Stals, E.; Huybrechts, B.; Waegeneers, N.; Delezie, E.; Van Pamel, E.; Daeseleire, E. Carry-Over of Mycotoxins to Animal Products: Case Study Poultry; Scientifec Report 211/212 CODA-CERVA (Centrum voor Onderzoek in Diergeneeskunde en Agrochemie-Centre d'Étude et de Recherches Vétérinaires et Agrochemiques): Brussels, Belgium, 2011-2012; pp. 141-144.

82. Leitgeb, R.; Raffaseder, C.; Ruckenbauer, P.; Lemmens, M.; Böhm, J.; Wagner, E.; Krska, R.; Parich, A. [impact of Fusarium toxins on growth and slaughter performance of broilers and turkeys]. Mycotoxin Res. 2003, 19, 180-184. [CrossRef] [PubMed]

83. Dorne, J.L.; Fink-Gremmels, J. Human and animal health risk assessments of chemicals in the food chain: Comparative aspects and future perspectives. Toxicol. Appl. Pharmacol. 2013, 270, 187-195. [CrossRef] [PubMed]

84. Ivanova, L.; Faeste, C.K.; Delezie, E.; Van Pamel, E.; Daeseleire, E.; Callebaut, A.; Uhlig, S. Presence of enniatin $\mathrm{b}$ and its hepatic metabolites in plasma and liver samples from broilers and eggs from laying hens. World Mycotoxin J. 2014, 7, 167-175. [CrossRef]

85. Barnes, D.M. Expression of p-glycoprotein in the chicken. Comp. Biochem. Physiol. Mol. Integr. Physiol. 2001, 130, 301-310. [CrossRef]

86. Wilkens, S. Structure and mechanism of ABC transporters. F1000Prime Rep. 2015, 7, 14. [CrossRef] [PubMed]

87. Fricker, G.; Miller, D.S. Relevance of multidrug resistance proteins for intestinal drug absorption in vitro and in vivo. Pharmacol. Toxicol. 2002, 90, 5-13. [CrossRef] [PubMed]

88. Shugarts, S.; Benet, L.Z. The role of transporters in the pharmacokinetics of orally administered drugs. Pharm. Res. 2009, 26, 2039-2054. [CrossRef] [PubMed]

89. Dornetshuber, R.; Heffeter, P.; Sulyok, M.; Schumacher, R.; Chiba, P.; Kopp, S.; Koellensperger, G.; Micksche, M.; Lemmens-Gruber, R.; Berger, W. Interactions between ABC-transport proteins and the secondary Fusarium metabolites enniatin and beauvericin. Mol. Nutr. Food Res. 2009, 53, 904-920. [CrossRef] [PubMed]

90. Commission Regulation (EC) No. 495/2011 of 20 may 2011 Amending Regulation (EC) No. 109/2007 as Regards the Composition of the Feed Additive Monensin Sodium; Official Journal of the European Union: Brussels, Belgium, 2011; Volume L 134/6.

91. Jestoi, M.; Rokka, M.; Järvenpää, E.; Peltonen, K. Determination of Fusarium mycotoxins beauvericin and enniatins $(a, a 1, b, b 1)$ in eggs of laying hens using liquid chromatography-tandem mass spectrometry (LC-MS/MS). Food Chem. 2009, 115, 1120-1127. [CrossRef]

92. Burmeister, H.R.; Ciegler, A.; Vesonder, R.F. Moniliformin, a metabolite of Fusarium moniliforme nrrl 6322: Purification and toxicity. Appl. Environ. Microbiol. 1979, 37, 11-13. [PubMed]

93. Springer, J.P.; Clardy, J.; Cole, R.J.; Kirksey, J.W.; Hill, R.K.; Carlson, R.M.; Isidor, J.L. Structure and synthesis of moniliformin, a novel cyclobutane microbial toxin. J. Am. Chem. Soc. 1974, 96, 2267-2268. [CrossRef] [PubMed]

94. Seifert, K.A.; Aoki, T.; Baayen, R.P.; Brayford, D.; Burgess, L.W.; Chulze, S.; Gams, W.; Geiser, D.; de Gruyter, J.; Leslie, J.F.; et al. The name Fusarium moniliforme should no longer be used. Mycol. Res. 2003, 107, 643-644. [CrossRef] 
95. Fotso, J.; Leslie, J.F.; Smith, J.S. Production of beauvericin, moniliformin, fusaproliferin, and fumonisins b-1, b-2, and b-3 by fifteen ex-type strains of Fusarium species. Appl. Environ. Microbiol. 2002, 68, 5195-5197. [CrossRef] [PubMed]

96. Schütt, F.; Nirenberg, H.I.; Demi, G. Moniliformin production in the genus Fusarium. Mycotoxin Res. 1998, 14, 35-40. [CrossRef] [PubMed]

97. Hallas-Møller, M.; Nielsen, K.F.; Frisvad, J.C. Production of the Fusarium mycotoxin moniliformin by Penicillium melanoconidium. J. Agric. Food Chem. 2016, 64, 4505-4510. [CrossRef] [PubMed]

98. Jonsson, M.; Jestoi, M.; Nathanail, A.V.; Kokkonen, U.M.; Anttila, M.; Koivisto, P.; Karhunen, P.; Peltonen, K. Application of OECD guideline 423 in assessing the acute oral toxicity of moniliformin. Food Chem. Toxicol. Int. J. Publ. Br. Ind. Biol. Res. Assoc. 2013, 53, 27-32. [CrossRef] [PubMed]

99. Jonsson, M.; Atosuo, J.; Jestoi, M.; Nathanail, A.V.; Kokkonen, U.M.; Anttila, M.; Koivisto, P.; Lilius, E.M.; Peltonen, K. Repeated dose 28-day oral toxicity study of moniliformin in rats. Toxicol. Lett. 2015, 233, 38-44. [CrossRef] [PubMed]

100. Pollock, G.A.; Disabatino, C.E.; Heimsch, R.C.; Hilbelink, D.R. The subchronic toxicity and teratogenicity of alternariol monomethyl ether produced by Alternaria solani. Food Chem. Toxicol. 1982, 20, 899-902. [CrossRef]

101. Griffin, G.F.; Chu, F.S. Toxicity of the Alternaria metabolites alternariol, alternariol methyl-ether, altenuene, and tenuazonic acid in the chicken-embryo assay. Appl. Environ. Microbiol. 1983, 46, 1420-1422. [PubMed]

102. Broomhead, J.N.; Ledoux, D.R.; Bermudez, A.J.; Rottinghaus, G.E. Chronic effects of moniliformin in broilers and turkeys fed dietary treatments to market age. Avian Dis. 2002, 46, 901-908. [CrossRef]

103. Li, Y.C.; Ledoux, D.R.; Bermudez, A.J.; Fritsche, K.L.; Rottinghaus, G.E. The individual and combined effects of fumonisin b1 and moniliformin on performance and selected immune parameters in turkey poults. Poult. Sci. 2000, 79, 871-878. [CrossRef] [PubMed]

104. Harvey, B.; Edrington, T.S.; Kubena, L.F.; Rottinghaus, G.E.; Turk, J.R.; Genovese, K.J.; Ziprin, R.L.; Nisbet, D.J. Toxicity of fumonisin from Fusarium verticillioides culture material and moniliformin from Fusarium fujikuroi culture material when fed singly and in combination to growing barrows. J. Food Prot. 2002, 65, 373-377. [CrossRef] [PubMed]

105. Pirrung, M.C.; Nauhaus, S.K.; Singh, B. Cofactor-directed, time-dependent inhibition of thiamine enzymes by the fungal toxin moniliformin. J. Org. Chem. 1996, 61, 2592-2593. [CrossRef] [PubMed]

106. Behrens, M.; Huwel, S.; Galla, H.J.; Humpf, H.U. Blood-brain barrier effects of the Fusarium mycotoxins deoxynivalenol, 3 acetyldeoxynivalenol, and moniliformin and their transfer to the brain. PLoS ONE 2015, 10, e0143640. [CrossRef] [PubMed]

107. Garganese, F.; Schena, L.; Siciliano, I.; Prigigallo, M.I.; Spadaro, D.; De Grassi, A.; Ippolito, A.; Sanzani, S.M. Characterization of citrus-associated Alternaria species in mediterranean areas. PLoS ONE 2016, 11, e0163255. [CrossRef] [PubMed]

108. Davis, V.M.; Stack, M.E. Mutagenicity of stemphyltoxin iii, a metabolite of Alternaria alternata. Appl. Environ. Microbiol. 1991, 57, 180-182. [PubMed]

109. Taniwaki, M.H.; Frisvad, J.C.; Ferranti, L.S.; Lopes, A.D.; Larsen, T.O.; Fungaro, M.H.P.; Iamanaka, B.T. Biodiversity of mycobiota throughout the Brazil nut supply chain: From rainforest to consumer. Food Microbiol. 2017, 61, 14-22. [CrossRef] [PubMed]

110. Solhaug, A.; Eriksen, G.S.; Holme, J.A. Mechanisms of action and toxicity of the mycotoxin alternariol: A review. Basic Clin. Pharmacol. Toxicol. 2016, 119, 533-539. [CrossRef] [PubMed]

111. Fehr, M.; Pahlke, G.; Fritz, J.; Christensen, M.O.; Boege, F.; Altemöller, M.; Podlech, J.; Marko, D. Alternariol acts as a topoisomerase poison, preferentially affecting the II alpha isoform. Mol. Nutr. Food Res. 2009, 53, 441-451. [CrossRef] [PubMed]

112. Solhaug, A.; Torgersen, M.L.; Holme, J.A.; Lagadic-Gossmann, D.; Eriksen, G.S. Autophagy and senescence, stress responses induced by the DNA-damaging mycotoxin alternariol. Toxicology 2014, 326, 119-129. [CrossRef] [PubMed]

113. Shigeura, H.T.; Gordon, C.N. Biological activity of tenuazonic acid. Biochemistry 1963, 2, $1132-1137$. [CrossRef] [PubMed]

114. Vejdovszky, K.; Warth, B.; Sulyok, M.; Marko, D. Non-synergistic cytotoxic effects of Fusarium and Alternaria toxin combinations in Caco-2 cells. Toxicol. Lett. 2016, 241, 1-8. [CrossRef] [PubMed]

115. Rychlik, M.; Lepper, H.; Weidner, C.; Asam, S. Risk evaluation of the Alternaria mycotoxin tenuazonic acid in foods for adults and infants and subsequent risk management. Food Control 2016, 68, 181-185. [CrossRef] 
116. Asam, S.; Habler, K.; Rychlik, M. Determination of tenuazonic acid in human urine by means of a stable isotope dilution assay. Anal. Bioanal. Chem. 2013, 405, 4149-4158. [CrossRef] [PubMed]

117. Schuchardt, S.; Ziemann, C.; Hansen, T. External Scientific Report on Combined Toxicokinetic and in vivo Genotoxicity Study on Alternaria Toxins; EN-679; EFSA Supporting Publication: Hannover, Germany, 2014. 